\title{
Fen Eğitimi Alanında Yapılan Bilimsel Süreç Becerilerini İçeren Lisansüstü Tezlerin İncelenmesi: Meta-Sentez Çalışması*
}

\author{
Analysis of Graduate Theses Containing Scientific Process Skills in Science Education: \\ Meta-Synthesis Study
}

\section{Aynur ÇEVIK ${ }^{1}$, Hasan KAYA ${ }^{2}$}

\footnotetext{
*Bu çalışma, birinci yazarın doktora tez çalışmasının bir bölümünden üretilmiştir. ${ }^{1}$ Doktora Öğrencisi., Erciyes Üniversitesi, acevik1406@gmail.com (D) 0000-0002-7032-6191

2Prof. Dr., Erciyes Üniversitesi, Matematik ve Fen Bilimleri Eğitimi, hasankaya@erciyes.edu.tr, 0000-0003-3529-9762
}

\begin{tabular}{|c|c|c|c|c|}
\hline \multicolumn{5}{|c|}{ Araştırma makalesi/ Research Article } \\
\hline Geliş: 2021-08-20 & 臬 & Kabul Tarihi: 2021-12-16 & 贯 & Yayın Tarihi: 2021-12-31 \\
\hline \multicolumn{5}{|c|}{$\begin{array}{l}\text { Atıf/Citation } \\
\text { Çevik, A \&Kaya, H. (2021). Fen eğitimi alanında yapılan bilimsel süreç becerilerini içeren lisansüstü } \\
\text { tezlerin incelenmesi: Meta-Sentez Çalışması. Maarif Mektepleri Uluslararası Ĕ̆itim Bilimleri Dergisi, } \\
\text { 5(2), 143-166. https://doi.org/10.46762/mamulebd.985454 }\end{array}$} \\
\hline \multicolumn{5}{|c|}{$\begin{array}{l}\text { Çevik, A \&Kaya, H. (2021). Analysis of graduate theses containing scientific process skills in science } \\
\text { education: Meta-Synthesis Study. Maarif Mektepleri International Journal of Educational Sciences, 5(2), } \\
\text { 143-166. https://doi.org/10.46762/mamulebd.985454 }\end{array}$} \\
\hline
\end{tabular}

Öz

Bu çalışmada, 2015-2021 yılları arasında Türkiye'de fen bilimleri alanında yapılmış bilimsel süreç becerilerini içeren lisansüstü tezlerinin incelenmesi amaçlanmıştır. Nitel araştırma desenlerinden meta-sentez ile yapılan bu çalışmada verilerin toplanmasında Yüksek Öğretim Kurulu (YÖK) Ulusal Tez Merkezi'nde bulunan "fen" ve "bilimsel süreç becerileri" anahtar kelimeleri kullanılmıştır. Çalışmanın amacı doğrultusunda incelenmek üzere beş doktora, 35 yüksek lisans tezi olmak üzere toplam 40 teze ulaşılmıştır. Tezlerin metaanalizinde, tezin türü, yılı, çalışma alanı, araştırma yöntemleri, örneklem grubu, örneklem belirleme yöntemleri, veri toplama araçları, veri analiz yöntemi ve sonuçları gibi kategoriler altında kodlar oluşturulmuştur. Analiz sonucunda elde edilen veriler, tablo ve grafikler halinde sunularak yorumlanmıştır. Araştırmanın sonunda; 2015-2021 yılları arasında bilimsel süreç becerilerini içeren tezlerin çoğunluğunun yüksek lisans tezi olduğu ve 2019 yılında yayımlandığı, tezlerde konu alanı olarak probleme dayalı öğrenmenin çoğunlukta olduğu 
tespit edilmiştir. Ayrıca incelenen tezlerde nicel araştırma yönteminin ve yarı deneysel desenin daha fazla tercih edildiği, çalışma grubu olarak yedinci sınıf öğrencileri, örneklem büyüklügünün ise çoğunlukla 40-60 kişiden oluştuğu, veri toplama aracı olarak bilimsel süreç becerileri ve başarı testinin daha çok kullanıldığı, veri analizi olarak t-testlerinin ve içerik analizinin daha çok kullanıldığı belirlenmiştir. Sonraki araştırmalar için yurt dişındaki tezleri de içerecek şekilde daha derinlemesine incelemeler yapılması önerilmiştir.

Anahtar Kelimeler: Bilimsel süreç becerileri, fen eğitimi, meta-sentez

\begin{abstract}
In this study, it is aimed to examine the postgraduate theses containing scientific process skills made in the field of science in Turkey between the years 2015 and 2021. The keywords "science" and "scientific process skills" in the National Thesis Center of the Council of Higher Education (YÖK) were used in the collection of data in this study, which was conducted with meta-synthesis, one of the qualitative research designs. In line with the aim of the study, a total of 40 theses, including five doctorate and 35 master's theses, were reached. In the meta-analysis of the theses, codes were created under categories such as the type and year of the thesis, field of study, research methods, sample group, sampling methods, data collection tools, data analysis method and results. The data obtained from analysis were presented in tables and graphs and interpreted. At the end of the research; It has been determined that the majority of theses containing scientific process skills between 2015-2021 were master's thesis and were published in 2019, and problem-based learning was the majority in the theses. In addition, in the theses examined, quantitative research method and quasi-experimental design were preferred more, seventh grade students as the study group, sample size mostly consisted of 40-60 people, scientific process skills and achievement test were used more as data collection tools, data analysis was used as data analysis. $t$-tests and content analysis were determined to be used more. For next research, it is recommended to conduct more in-depth studies, including theses abroad.
\end{abstract}

Keywords: Science process skills, science education, meta-synthesis

\title{
Giriş
}

Bilim ve teknolojideki gelişim ve değişim, günümüzde gereksinim duyulan nitelikli insan tanımındaki değişimi de beraberinde getirmiştir (Millî Eğitim Bakanlığı [MEB], 2018). Bireysel farklılıkların arttığı günümüzde, bilgiye ulaşma yollarını öğrenmiş, üretken ve yaratıcı bireyler yetiştirmek toplumlar için büyük önem kazanmıştır. Bu hızlı değişimler toplumsal yaşantıları da etkilemiş, toplumlardaki değer yargıları, bireyin toplumdan ve toplumun bireyden beklentileri büyük ölçüde değişmiştir (MEB, 2018). Fen eğitiminin amacı da dünyada olan bu gelişmeleri yakından takip edebilmek için araştıran, sorgulayan ve bilgiye ulaşma yollarını bilen, aynı zamanda öğrendiği bu bilgilerle günlük yaşamında karşılaştığ1 sorunları çözebilen bireyler yetiştirmektir (Başdağ, 2006). Bireylerin günlük yaşantılarında karşılaştıkları sorunlara çözüm bulmada farklı yollar takip edilebilir. Bilimsel süreç becerileri bu yollardan biridir. 
Bilimsel süreç becerileri (BSB)'nin araştırmacılar tarafından farklı şekillerde tanımlandığ1 görülmektedir. Tobin ve Capie (1982) tarafından "bir problemin çözümüne ilişkin verileri toplanma ve analiz etmede kullanılan beceriler" olarak, Padilla, Okey ve Dillashaw (1983) tarafından "formal işlem döneminde gelişen önce somut düzeyde başlayan akıl yürütme ve düşünme stratejileri" olarak, Rezba, Sprague, Fiel ve Funk (1995) "düşünmenin bileşenlerini oluşturan ve bilim insanlarının kullandıkları yöntemler olarak, Anagün ve Yaşar (2009) ise "bilgiyi yapılandırmada, problemler hakkında mantık yürütmede ve sonuçları formüle etmede kullanılan beceriler" olarak tanımlanmıştır. Vitti ve Torres (2006) BSB'nin zihnimizde kendiliğinden oluştuğunu, mantıksal olarak kendi düşüncelerimizi adımlara ayırmanın yanı sıra hem bilimde hem de kritik düşünmenin gerektiği durumlarda kullanıldığını, ayrıca BSB'nin gözlem yapma, ölçme, sonuç çıkarma, tahmin etme, deney yapma ve iletişim kurma gibi becerileri de içerdiğini vurgulamıştır.

BSB'nin nelerden oluştuğu ve bu becerilerin düzeylerine ilişkin literatürde farklı sınıflandırmalar yapılmış olsa dabaşlıca üç grupta ele alınmıştır. Bunlar; Temel beceriler (Gözlem yapma, ölçme, sınıflama, verileri kaydetme, sayı ve uzay ilişkileri kurma), Nedensel beceriler (Önceden kestirme, değişkenleri tanıabilme, verileri yorumlama, sonuç çıkarma) ve Deneysel beceriler (Hipotez kurma ve tanımlama, verileri kullanma ve model oluşturma, deney yapma, değişkenleri değiştirme ve kontrol etme, karar verme) dir (Batı ve Kaptan, 2013; Zorlu, Zorlu, Sezek ve Akkuş, 2014).

Öğrencilerin BSB'nin geliştirilmesi onlara eleştirel düşünme, analitik düşünme, sorgulama, problem çözme, sorumluluk alma bilinci, öğrenmede kalıcılığı artırma, karar verme ve günlük yaşamda kullanılabilecek becerileri kazandırır. Bu nedenle BSB sadece fen öğretiminde değil, aynı zamanda diğer derslerin öğretiminde de büyük bir öneme sahiptir (Hazır ve Türkmen, 2008; Rehorek, 2004; Myers, Washburn ve Dyer, 2004). Bu nedenle, $1960^{\prime} 1$ y yllarda American Association for the Advancement of Science (A.A.A.S.)'in desteği ile hazırlanan Science-A Process Approach (S-APA) programı, fen bilimlerinde BSB'nin öğretimine ilişkin hazırlanan programların en önemlilerinden birini oluşturmaktadır (Kaptan, 1999). Bunu takip eden yıllarda, BSB gelişmiş ülkelerin öğretim programlarında ve ders kitaplarında sistematik bir şekilde yer alarak, öğrenci ve öğretmen ders kitaplarında birbirini tamamlamıştır. Öğrenci kitaplarl; a) bilimsel süreç becerileri b) eleştirel düşünme becerileri c) bilimsel muhakeme becerileri olmak üzere üç yönlü düşünme becerileri göz önünde bulundurularak hazırlanırken, öğretmen kitapları; bu becerilerin değerlendirilmesinde yardımcı olacak içerik ve görsel unsurlarla donatılmışır (Dökme, 2005).

Ülkemizde, Millı̂ Eğitim Bakanlığı'nın (MEB) fen bilimleri derslerinde BSB'nin kazandırılmasına büyük önem verdiği görülmektedir. Öğrencilerin erken yaşta bilimsel süreç becerileri ile donatılmasını sağlamak amacı ile okul öncesi eğitim programında BSB'ye açıkça yer verilmiştir (MEB, 2013). BSB'nin geliştirilmesi 2005 fen 
ve teknoloji dersi öğretim programında (MEB, 2005) en temel ve en kapsamlı hedef olarak belirlenirken, 2013 fen bilimleri dersi öğretim programında (MEB, 2013) ise BSB, yaşam becerileri ile birlikte beceri öğrenme alanı içerisinde ele alınmıştır. 2013 fen bilimleri dersi öğretim programı ile bilimsel süreç becerileri açısından benzerlik gösteren 2018 fen bilimleri dersi öğretim programında (MEB, 2018), mühendislik, girişimcilik, inovatif düşünme becerileri gibi konulara ağırlık verilerek Fen-TeknolojiMühendislik-Matematik (STEM) yaklaşımının benimsendiği görülmektedir (MEB, 2018).

BSB'ne yönelik yapılan araştırmalar, fen bilgisi öğretmen ve öğretmen adaylarının (Bahar, 2006; Farsakoğlu, Şahin, Karslı, Akpınar ve Ültay, 2008; Karslı, Şahin ve Ayas, 2009; Kozcu Çakır ve Sarıkaya, 2018), okul öncesi öğretmenlerinin (Batı, Ertürk ve Kaptan, 2010) ve sinıf öğretmenlerinin (Bowen ve Roth, 2005; Türkmen ve Kandemir, 2011) yeterli bilgiye sahip olmadıkları ortaya koyulmaktadır. Oysaki öğrenciler üzerine yapılan çalışmalarda, BSB'nin akademik becerilerin artırılmasında etkili olduğu (Zorlu, Zorlu, Sezek ve Akkuş, 2014), öğrencilerin zihinsel gelişiminde, öğrenmelerinin kalıcılığında, problem çözme becerisinin gelişiminde etkili olduğu (Arslan ve Tertemiz, 2004; Tan ve Temiz, 2003) ve bilimsel yaratıcllklarının gelişmesini olumlu yönde etkilendiği (Şahin-Pekmez, Aktamış ve Can, 2010) belirtilmektedir. Geniş bir açıdan bakıldığında BSB öğrencilerin eğitim hayatında önemli bir yer tuttuğu ve sınıf düzeyine göre ise gelişim gösterdiği (Özdemir, Özdemir, \& Parmaksız, 2017) vurgulanmıştır.

Türkiye'de yapılan çalışmalarda, BSB'ne ilişkin ölçek geliştirme (Aktamış ve Şahin-Pekmez, 2011; Alisinanoğlu, Bay ve Şimşek, 2014; Aydoğdu, Tatar, Yıldız ve Buldur, 2012; Şimşek-Çetin, Bay, Alisinanoğlu, 2014; Hazır ve Türkmen, 2008; Karslı ve Ayas, 2013; Kefi, 2018), BSB düzeylerinin cinsiyet (Karar, 2011; Kaymakc1, 2014), ailenin sosyo-ekonomik durumu (Aydınll, 2007; Öztürk, 2008), öğrencilerin öğrenim gördükleri okul türü (Çakar, 2008; Kaymakc1, 2014) anne ve babanın eğitim durumu (Aydınll, 2007; Çakar, 2008; Özdemir Tümer, 2009) gibi değişkenlerle olan ilişkisinin araştırıldığı görülmektedir. Ancak fen eğitiminde BSB ile ilgili meta-sentez çalışmalarının oldukça sınırlı sayıda olduğu tespit edilmiştir.

Yıldırım, Çalık ve Özmen (2016) tarafından yapılan meta-sentez çalışmasında; BSB ile ilgili 2000-2015 yılları arasında Türkiye'de yapılan 200 bilimsel çalışma incelenmiştir. İncelenen çalışmaların 175' $\mathrm{i}$ makale ve $25^{\prime} \mathrm{i}$ ise 2007-2015 yılları arasında tamamlanan lisansüstü tezlerdir. Meta-sentez çalışması yapılan çalışmaların 136'sında öğrencilerin beceri geliştirmesi ve/veya başarısını etkileyen değişkenler; 13'ünde öğretmen görüşleri; 12 'sinde fen bilimleri müfredat1; 11'inde fen ders kitabının incelenmesi; 11' inda BSB ile fen öğretimi; 8 'inde ölçek geliştirme; 8 'inde BSB'nin diğer değişkenler (tutum, eleştirel düşünme, bilimsel yaratıcllk) ile ilişkisi; 1'inde ise yükseköğretim kurumlarına geçiş sınavlarının BSB yönünden değerlendirildiği tespit edilmiştir. Yapılan araştırmaların 67' si ortaokul, 26's ilkokul, 15'i lise ve 1'i okul öncesi öğrencileriyle; 63'ü öğretmen adaylarıyla; 15'i öğretmenlerle olduğu tespit edilmiştir. Yıldırım, Çalık ve Özmen (2016) tarafından yürütülen bu araştırmanın fen eğitimi 
literatürüne olumlu katkı sağlamakla beraber 2000-2015 yılları ile sınırlı kaldığı ve bu nedenle 2015 yılından sonra tamamlanan tez çalışmaları için yeni bir meta-sentez çalışmasının yapılmasına ihtiyaç olduğu düşünülerek bu araştırma yapılmıştır.

Meta-Sentez çalışmaları diğer araştırmacılara yol gösteren önemli çalışmalar arasındadır. Bu kapsamda BSB'ne ilişkin fen eğitimi alanında ülkemizde 2015-2021 yılları arasında yapılan tez çalışmalarının betimsel bir mantıkla analiz edilmesi ve sonraki araştırmacılara sunulması gelecekte fen eğitimi alanında yapılacak çalışmaların etkililiğini artıracağı düşünülmüştür. Ülkemizin önemli veri tabanlarından biri olan YÖK Tez ulusal veri tabanında yer alan ve BSB ile ilgili fen eğitimi alanında tamamlanmış yüksek lisans ve doktora tezlerinin incelenmesi amaçlanmıştır. Bu amaçla aşağıdaki sorulara cevap aranmıştır:

BSB ile ilgili fen eğitimi alanında 2015-2021 yıları arasında tamamlanan tezlerin; 1) türüne, 2) yıllara, 3) araştırma konusuna, 4) araştırma yöntemine, 5) araştırma desenine, 6) örneklem gruplarına, 7) örneklem büyüklügüne, 8) kullanılan veri toplama aracına, 9) veri analiz türüne ve 10) amaç ve sonuçlarına göre dağılımı nasildır?

\section{Yöntem}

\section{Araştırma Deseni}

YÖK Ulusal Tez Merkezi veri tabanında yer alan 2015- 2021 yılları arasında bilimsel süreç becerileri ile ilgili fen eğitimi alanında hazırlanmış ve erişime açık tezlerin incelenmesi amacıyla yürütülen bu çalışmada, nitel araştırmalarda kullanılan içerik analizi çalışmalarının sonuçlarını sentezleyen meta-sentez çalışması kullanılmıştır. Meta sentez çok sayıda araştırma bulgularının incelenip yorumlanması olarak tanımlanmaktadır (Finfgeld, 2003). Bu yöntemde belli bir konu ya da alanda yapılmış olan çalışmaların karşılaştırılıp benzer ve farklı yönlerinin tespit edilmesi ve ulaşılan sonuçların değerlendirilmesi öngörülmektedir. Meta-sentez çalışmaları da meta-analiz gibi diğer analizlere göre incelenen makale veya tez sayısı daha sinırlıdır (Çalık ve Sözbilir, 2014). Bu çalışmada meta-sentez kullanılmasının sebebi amaç doğrultusunda ele alınan tezlerin benzerlik ve farklılıklarını analiz edip incelemektir. Ayrıca bu çalışmada, elde edilen verileri benzerlik durumlarına göre temalar oluşturarak kolay anlaşılmalarını sağlamak amacıyla içerik analizinden de yararlanılmıştır.

\section{Verilerin Toplanması ve Araştırmaya Dahil Edilme Kriterleri}

Araştırmanın örneklemi, YÖK Ulusal Tez Merkezi'nde (http://tez.yok.gov.tr/) bulunan "fen" ve "bilimsel süreç becerileri" anahtar kelimeleri kullanılarak ulaşılan, 2015-2021 yılları arasında tamamlanmış ve erişime açı olan lisansüstü tezlerdir. Araştırma yapılırken tez adları ve içerikleri dikkate alınmıştır. Yapılan bu araştırma kapsamında incelenen tezlerin belirlenmesinde dikkate alınan ölçütler aşağıdaki gibidir. 
- Çalışmanın fen eğitimi alanında yapılmış olması,

- Çalışmanın bilimsel süreç becerilerini kapsaması,

- Çalışmanın yüksek lisans veya doktora tezi olması,

- Çalışmaların 2015-2021 yıllarında yayınlanmış olması,

- Çalışmaların Türkiye'de yapılmış olması,

- Tam metnine ulaşılabiliyor olması.

Çalışmanın amacı doğrultusunda incelenmek üzere tam metnine erişim sağlanabilen 40 adet fen bilimleri eğitimi alanındaki lisansüstü teze ulaşılmıştır (Ek-1).

\section{Verilerin Kodlanması}

Araştırmada kodlamaya geçilmeden önce incelenen tezlerin bütün kısımları ayrıntılı bir şekilde okunmuştur. İncelenecek tezler T1, T2...T21 şeklinde kodlandıktan sonra araştırma problemleri doğrultusunda kategori ve kodlar oluşturularak analiz yapılmıştır. Bu çalışmada kategoriler oluşturulurken; tez türü ve yayınlanma tarihi, araştırma konusu, araştırma yöntemi, örneklem grubu, örneklem büyüklügüu, veri toplama araçları, veri analizi ve amaç ve sonuçlarına göre irdelenerek on farklı konu başlığı altında toplanmıştır. Bu kategorilere göre de uygun kodlar belirlenmiştir.

\section{Geçerlik Çalışması}

Araştırmanın geçerliliği kapsamında incelenmek üzere belirlenen tezlere ilişkin oluşturulan kod ve kategoriler fen eğitimi alanında uzman iki öğretim üyesi tarafından incelenmiş ve uzman görüşü doğrultusunda gerekli düzeltmeler yapılmıştır.

\section{Verilerin Analizi}

Bu araştırmada, Türkiye'de 2015-2021 yılları arasında fen eğitimi alanında ve BSB ile ilgili tamamlanan lisansüstü tezleri tarama işlemi Nisan 2021- Mayıs 2021 tarihleri arasında yapılmıştır. Ulaşılan tezlerin ilgili parametrelere aktarımı, Mayıs 2021 tarihlerinde gerçekleştirilmiştir. Bu nedenle 2021-Mayıs ayından sonra tamamlanan tezler bu araştırmaya dahil edilmemiştir. Tarama sonucu ulaşılan tezlerin, bu araştırmaya uygunluğu konusunda uzman görüşüne başvurulmuştur. Uygun bulunan tezler tam metin olarak kayıt altına alınmıştır. Bu araştırmaların her biri belli bir kategori altında Excel'de kodlanmıştır. Bu kategoriler; tezin türü, yayın yılı, konu alanları, araştırma deseni, veri toplama araçları, örneklem grubu ve sayıları, analiz yöntemi, araştırmanın amacı ve sonuçları olarak belirlenmiştir. Böylece araştırma sonunda daha kapsamlı verilere ulaşılması hedeflenmiştir. Oluşturulan bu kategori ve kodlara göre çalışmaya dâhil edilen tezlerin dağılımı grafikler şeklinde gösterilmiştir. Grafiklerde istatistik veri olarak yüzde ve frekans değerleri verilmiş, bu değerler doğrultusunda yorum yapılmıştır. 


\section{Bulgular}

Araştırmanın bulguları, bilimsel süreç becerilerine yönelik fen eğitimi alanında yapılan 2015-2021 yılları arasinda tamamlanan 40 tezin meta-analizinde elde edilmiştir. Fen eğitimi alanında ve BSB'ne yönelik yapılan tezlerin türlerine göre bulguları Şekil 1'de gösterilmiştir.

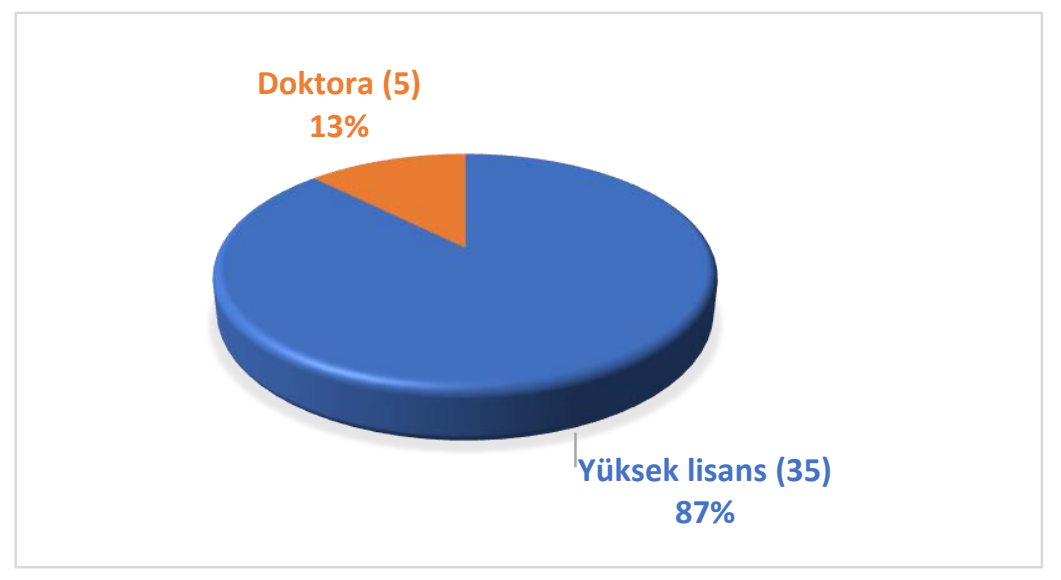

Şekil 1. Tezlerin yüksek lisans ve doktora düzeylerine göre dağılımı

Şekil 1'e göre bilimsel süreç becerilerine yönelik fen eğitimi alanında yapılan tezlerin türlerine göre dağılımı incelendiğinde, belirlenen aralıkta tamamlanan tezlerin \%87'si yüksek lisans, \%13'ü ise doktora tezinden oluştuğu görülmüştür.

Bilimsel süreç becerilerine yönelik ortaokul fen bilimleri alanında yapılan tezlerin yayınlandıkları yıllara göre dağılımlar Şekil 2'de gösterilmiştir.

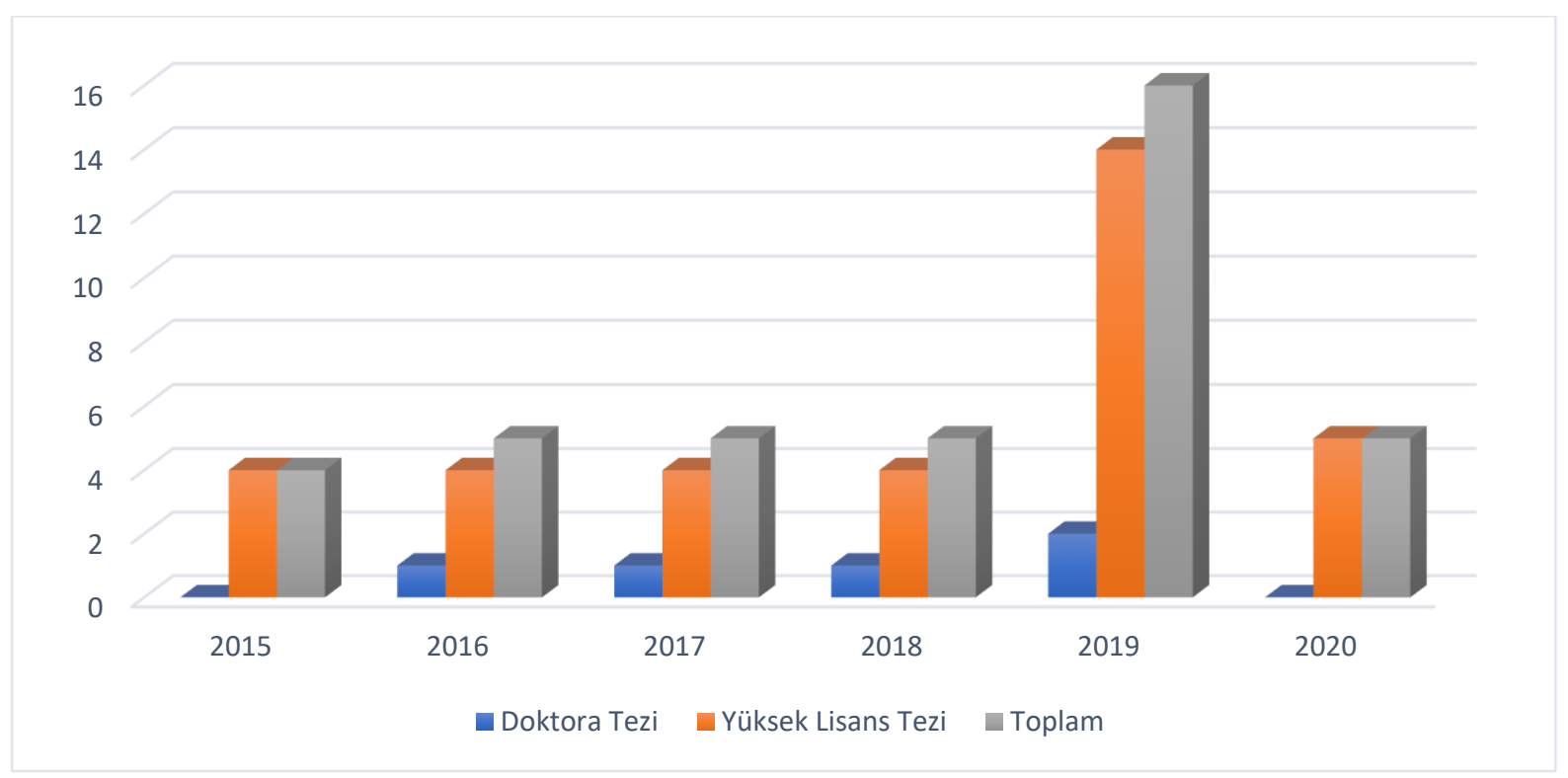

Şekil 2. Tezlerin yıllara göre dă̆ılımı

Şekil 2'de bilimsel süreç becerilerine yönelik fen alanında yapılan tezlerin yıllara göre dağılımına bakıldığında 2019 yılı hariç diğer yıllardaki tez sayısının yaklaşık olarak aynı olduğu, 2019 yılında ise 16 tez yayınlandığı görülmekte olup yüksek lisans 
ve doktora tezlerinin \%40'1 2019 yılında yayınlanmıştır. Doktora tezi olarak yayınlanan tezler 2016, 2017, 2018 ve 2019 yıllarında görülmekte, yüksek lisans olarak yayınlanan tezler ise araştırmaya dahil olan bütün yıllarda görülmektedir.

Bilimsel süreç becerilerine yönelik ortaokul fen bilimleri alanında yapılan tezlerin araştırma alanlarına göre bulguları Şekil 3'te gösterilmiştir.

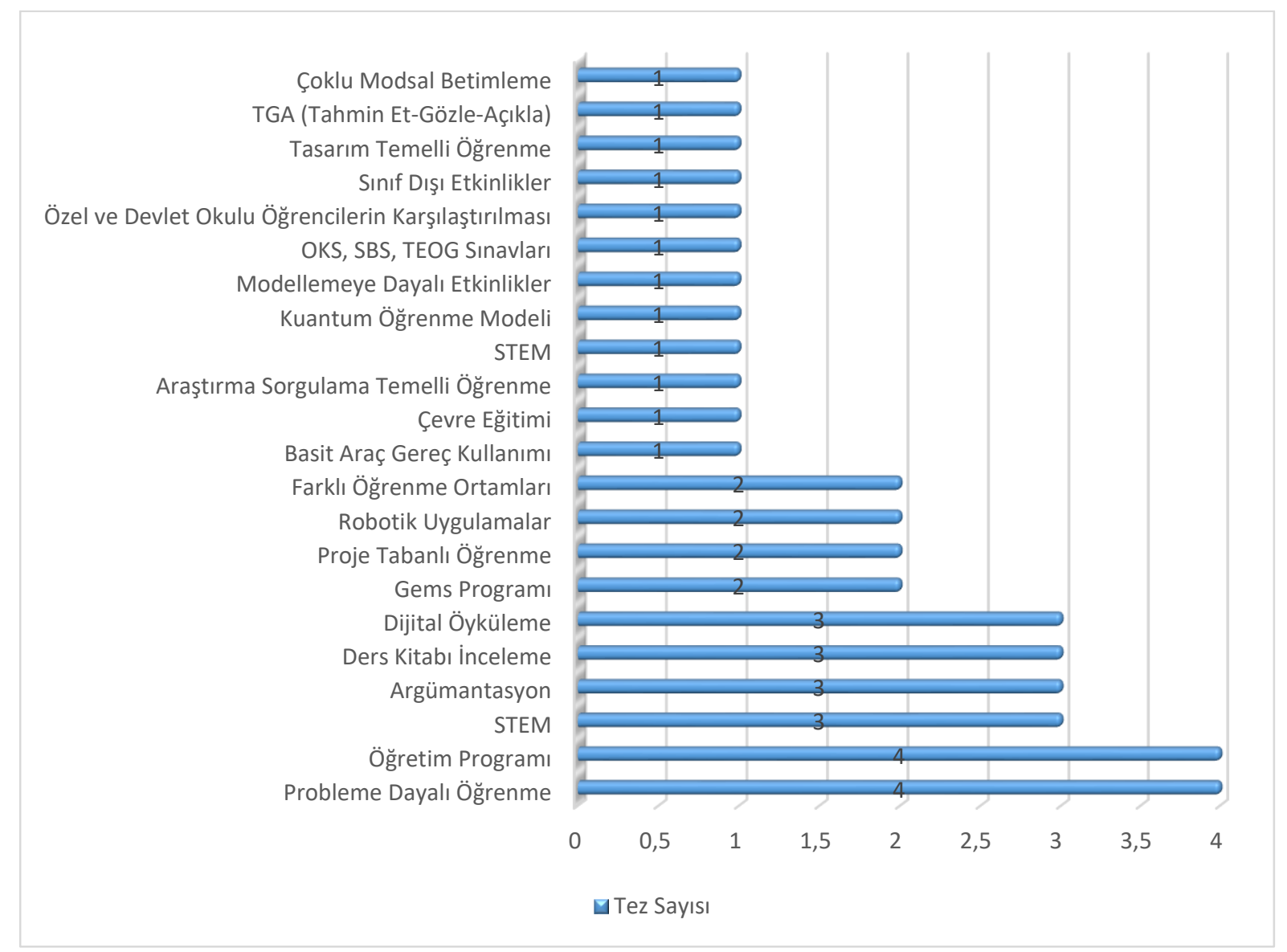

Şekil 3. Tezlerin araştırma konularına göre dă̆ılımı

Şekil 3'te BSB’ne yönelik fen eğitimi alanında yapılan tezlerin araştırma konularına incelendiğinde, probleme dayalı öğrenmeye ve fen öğretim programları konularına ilişkin dörder tez STEM, argümantasyon, dijital öyküleme konularına ilişkin üçer tez, Gems programı, proje tabanlı öğrenme, robotik uygulamalar ve farklı öğrenme ortamları konularında ikişer tez yapıldığı görülmüştür. Diğer 14 farklı konuların her birinde birer tez hazırlanmış olduğu tespit edilmiştir.

BSB'ye yönelik fen eğitimi alanında yapılan lisansüstü tezlerin kullanılan araştırma yöntemlerine göre dağılımı Şekil 4'te sunulmuştur. 


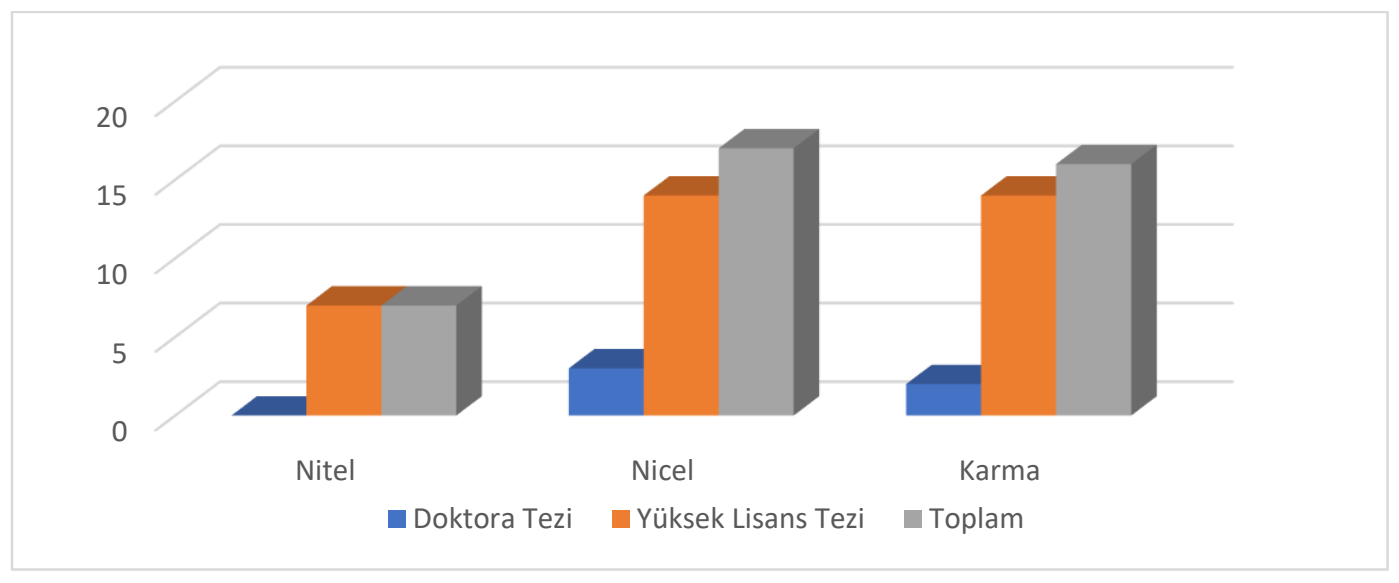

Şekil 4. Tezlerin araştırma yöntemlerine göre dă̆̆lımı

Şekil 4, lisansüstü tezlerinde kullanılan araştırma yöntemlerini göstermektedir. Şekilden de anlaşılacağı üzere, yapılan tez çalışmalarının büyük bir çoğunluğunda nicel araştırma yöntemi tercih edilmekle birlikte, karma yöntemin kullanıldı̆̆ı tezlerin sayısının nicel yöntemle yapılan tezlerin sayısına oldukça yakın olduğu görülmektedir. Doktor tezlerinde nicel yöntemin diğer yöntemlere göre daha fazla tercih edildiği, yüksek lisans tezlerinde ise nicel ve karma yöntemin yaklaşık eşit sayıda ve nitel yönteme göre daha fazla sayıda tercih edildiği görülmektedir.

BSB’ye yönelik fen eğitimi alanında yapılan tezlerin araştırma desenlerine göre dağılımı Şekil 5'te gösterilmiştir.

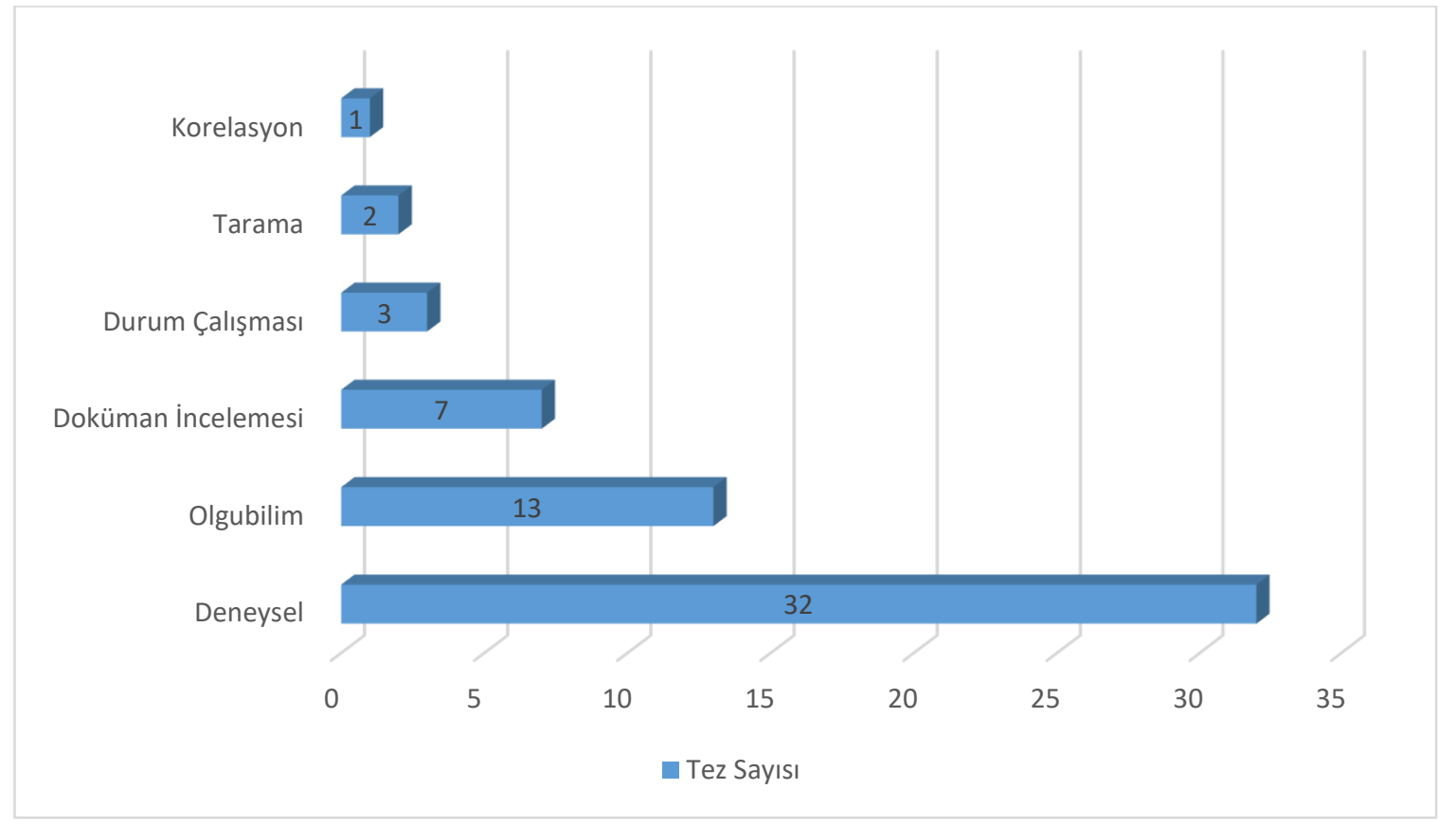

Şekil 5. Tezlerin araştırma desenine göre dă̆ılımı

Şekil 5'teki verilere bakıldığında, fen eğitiminde yapılan lisansüstü tez çalışmalarında ağırlıklı olarak deneysel desenin $(n=32)$ araştırma görülmektedir. Tezlerde olgubilim $(n=13)$ ve doküman incelemesi $(n=7)$ araştırmalarına da yer 
verilmekle birlikte, korelasyon'un kullanıldığı sadece bir tez çalışmasının yapıldığ görülmektedir.

BSB'ye yönelik fen eğitimi alanında yapılan tezlerin örneklem gruplarına göre dağılımı Şekil $6^{\prime}$ da gösterilmiştir. Fen eğitimi alanındaki lisansüstü tezlerinde kullanılan örneklem grubunun dağılımı incelendiğinde, en fazla tercih edilen örneklem grubunun yedinci sınıf $(n=14)$ ve altıncı sınıf $(n=11)$ düzeyindeki öğrenciler oluduğu görülmektedir (Şekil 6).

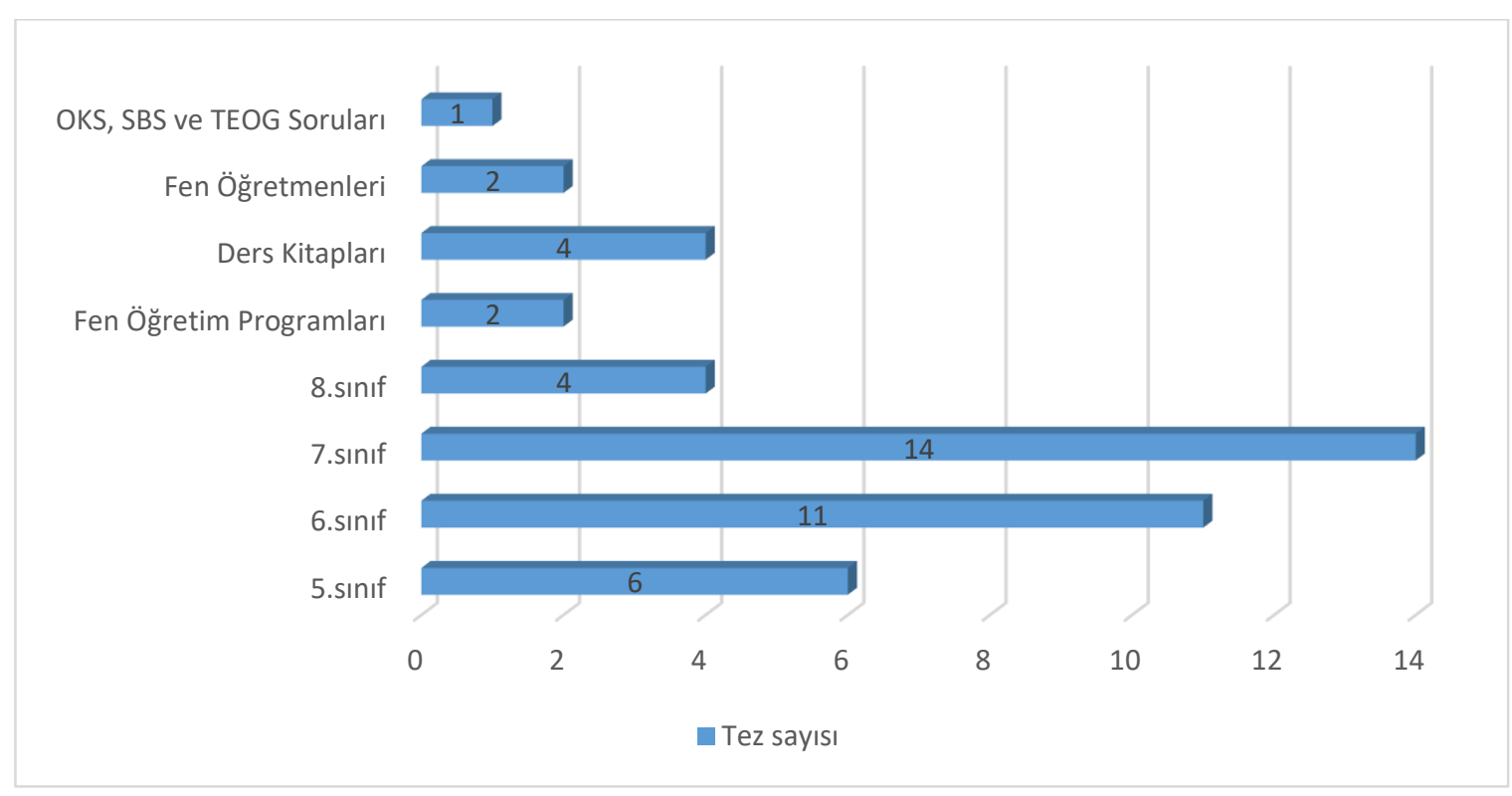

Şekil 6. Tezlerin örneklem grubuna göre dağıllmı

Beşinci sınıf $(n=6)$ ve sekicin sınıf $(n=4)$ düzeyindeki öğrencilerden daha az veri toplandığı, özellikle fen bilimleri öğretmenlerinden $(n=2)$ yeterince veri toplanmadığ tespit edilmiştir. Tez çalışmalarında, ders kitapları $(\mathrm{n}=2)$ fen öğretim programlarının da $(n=2)$ örneklem olarak kullanıldığı tez çalışmaları da bulunmaktadır.

Fen eğitimi alanında yapılan BSB ile ilgili tezlerin örneklem büyüklüklerine ilişkin yapılan analiz sonuçları Şekil 7'de sunulmuştur.

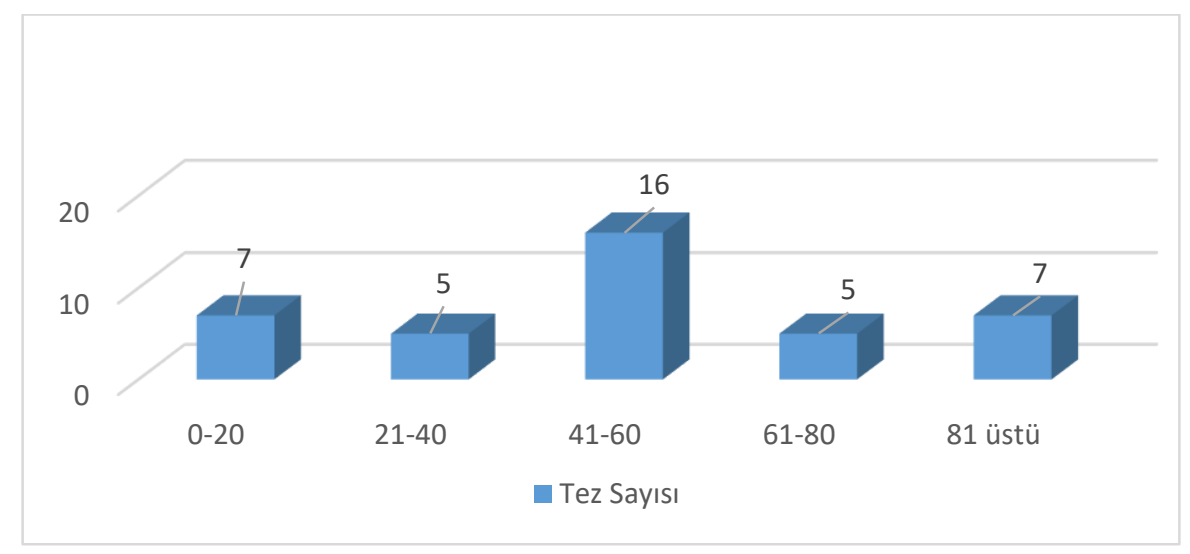

Şekil 7. Tezlerin örneklem büyüklü̆̆̈̈ne göre dağılımı 
Fen eğitimi ve BSB'ne ilişkin tezlerde kullanılan örneklem büyüklüğünün Şekil 7'deki dağılımı incelendiğinde, en fazla 41-60 (n=16) arası örneklem büyüklüklerinin tercih edildiği görülmüştür. 0-20 ve 80 üstü örneklem büyüklüğü ile yapılan tez sayıları eşit ve beşer tane iken, 21-40 ve 61-80 arası örneklem büyüklüğü ile yapılan tezlerin beşer tane olduğu tespit edilmiştir.

İncelenen lisansüstü tezlerde kullanılan veri toplama araçları ve kullanılma sıklığı değerlerine ilişkin analiz sonuçları Şekil 8' de gösterilmiştir.

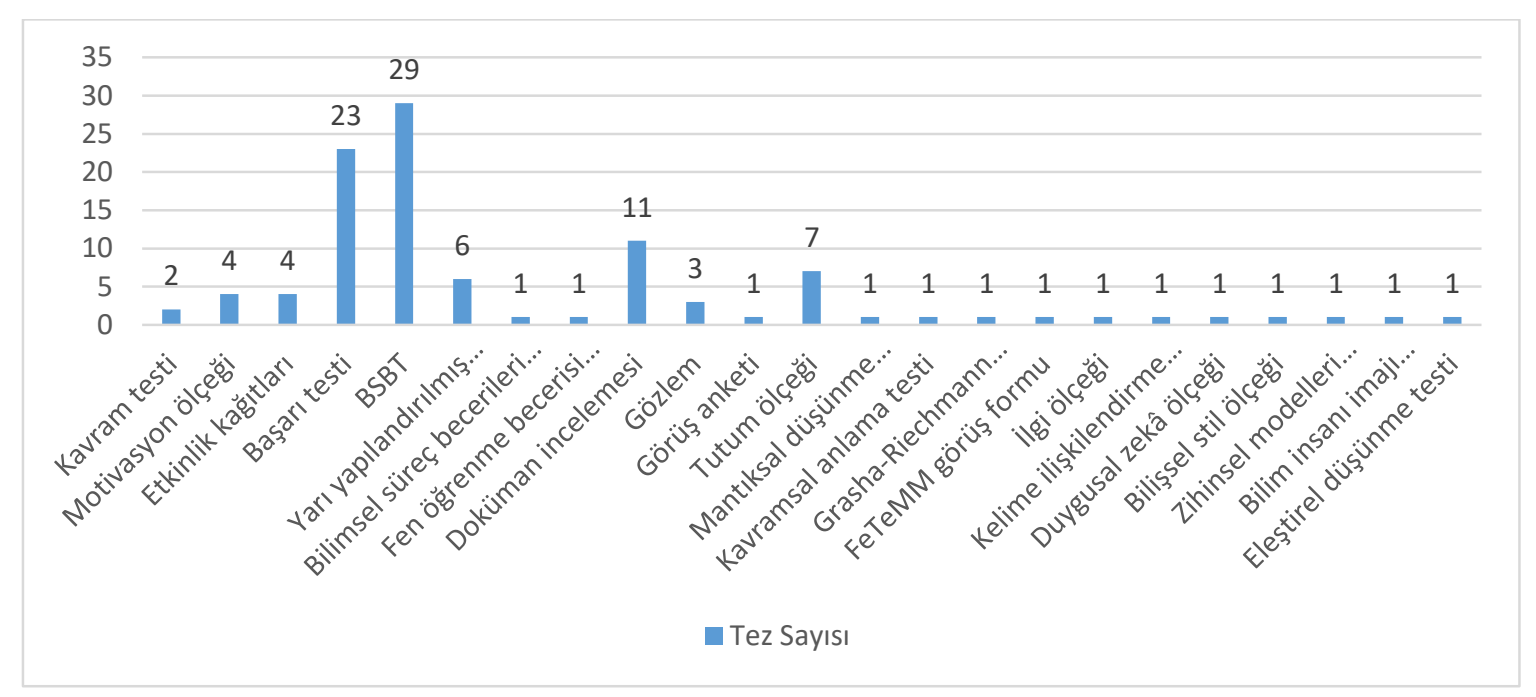

Şekil 8. Tezlerin veri toplama araçlarına göre dă̆̆llımı

Şekil 8 incelendiğinde tezlerde en fazla bilimsel süreç becerileri testi (BSBT) (n=29) ve başarı testi (n=26) kullanıldığı görülmüştür. Sonrasında ise sırayla doküman incelemesi $(n=11)$, tutum ölçeği $(n=7)$, yarı yapılandırılmış görüşme formu $(n=6)$, etkinlik kağıtları $(n=4)$, motivasyon ölçeği $(n=4)$ gelmektedir Veri toplama aracı olarak diğerlerinden daha az kullanılan araçlar ise ilgi, bilişsel stil, duygusal zekâ ölçekleri kullanılmıştır. Şekil 8 incelendiğinde kullanılan veri toplama araçlarının incelenen tezlerin sayısından daha fazla olduğu görülmektedir. Bunun fazlalığın sebebi incelenen bazı tezlerde birden fazla veri toplama aracının kullanilmasından kaynaklanmaktadır.

Tezlerde kullanılan veri analiz yöntemleri ve kullanılma sıklığı değerleri Şekil 9'da gösterilmiştir. 


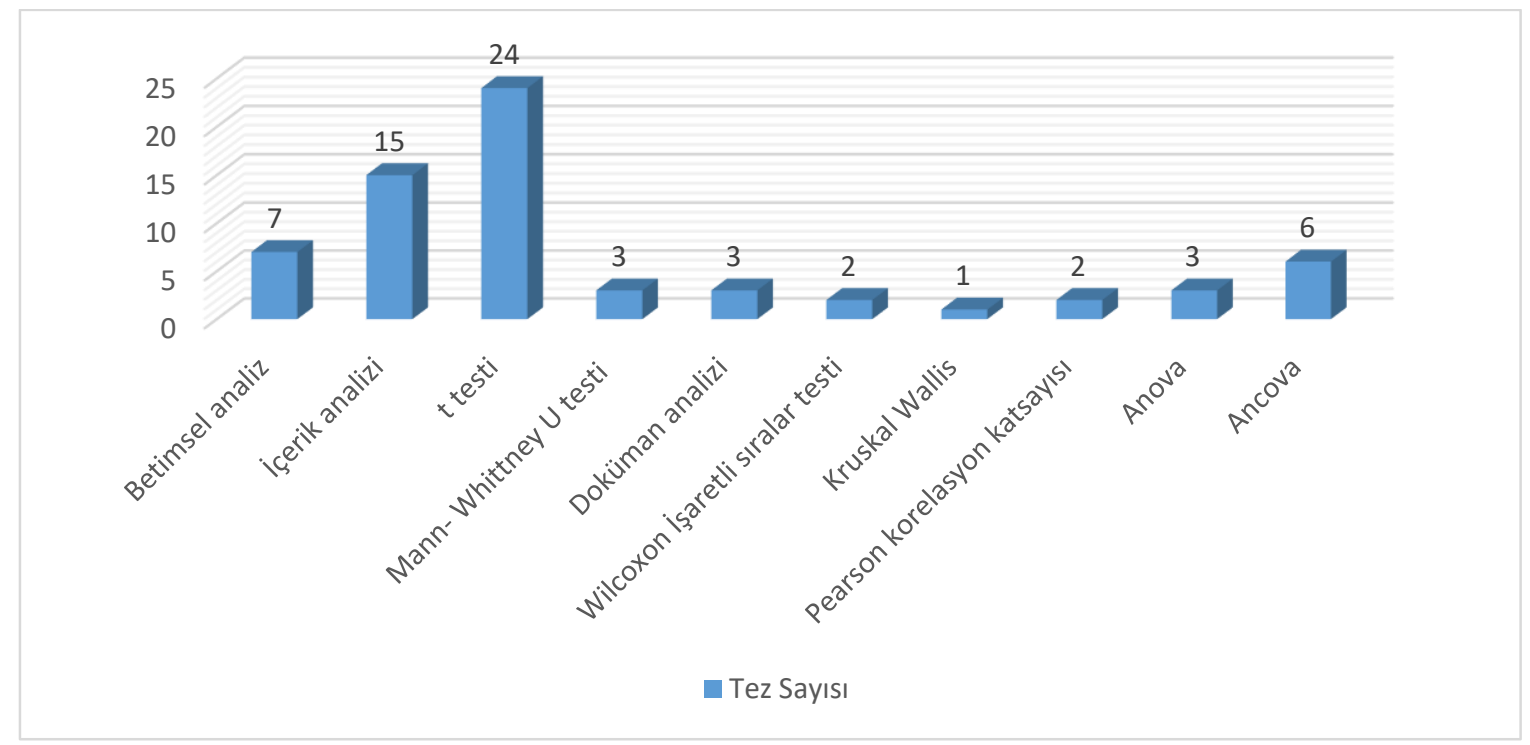

Şekil 9. İncelenen tezlerin kullanılan analiz yöntemlerine göre dă̆glımı

Şekil 9' a göre incelenen tezlerde kullanılan araştırma yöntemlerine paralel olarak en fazla kullanılan veri analiz yöntemlerinin bağımlı - bağımsız t- testi ( $n=24)$ olduğu görülmektedir. Karma ve nitel araştırma yöntemlerinin kullanıldığı tezlerde ise içerik analizi ( $n=15)$ ve betimsel analiz ( $n=7)$ gibi nitel analiz yöntemleri de kullanıldı̆̆ edilmiştir. Bunun yanı sıra incelenen tezlerde normal dağılımın sağlanmadığı veya yeterli örneklem sayısına ulaşılmayan nicel çalışmalarda parametrik olmayan istatistiksel analiz yöntemlerinin de $(n=5)$ kullanıldı̆̆ı görülmüştür.

BSB'ye ilişkin fen eğitimi alanında yapılan tezlerin amaç ve sonuçlarına göre bulguları Tablo 1' de gösterilmiştir.

Tablo 1. Incelenen tezlerin amaç ve sonuçlarına ilişkin göre dă̆ılımı

\begin{tabular}{|c|c|c|}
\hline Amaç & Sonuç & Tez No \\
\hline $\begin{array}{l}\text { Ders kitaplarındaki } \\
\text { etkinliklerin BSB'yi ne } \\
\text { düzeyde temsil edildiğini } \\
\text { belirlemek }\end{array}$ & $\begin{array}{l}\text { Ders kitaplarındaki etkinliklerde gözlem } \\
\text { yapma, karşılaştırma, iletişim kurma, verileri } \\
\text { toplama ve kaydetme, tahmin etme, verileri } \\
\text { yorumlama becerilerine daha fazla yer } \\
\text { verilmiştir }\end{array}$ & T1, T4, T37 \\
\hline $\begin{array}{l}\text { Kullanılan yöntem/tekniğin } \\
\text { BSB'ne etkisini araştırmak }\end{array}$ & $\begin{array}{l}\text { Örnek olay, proje tabanlı öğrenme, dijital } \\
\text { öyküleme, kuantum öğrenme modeli, robotik } \\
\text { kodlama, araştırma sorgulama, tasarım temelli } \\
\text { öğrenme, GEMS, FeTeMM, probleme dayalı } \\
\text { öğrenme, argümantasyon, STEM, TGA, okul } \\
\text { dışı öğrenme, çoklu modsal betimleme ve } \\
\text { modellemeye dayalı öğrenme yöntemlerinin } \\
\text { BSB'ni arttırmaya yönelik olumlu etkileri } \\
\text { görülmüştür. }\end{array}$ & $\begin{array}{l}\text { T2, T3, T5, T6, } \\
\text { T7, T8, T9, T11, } \\
\text { T13, T14, T15, } \\
\text { T17, T19, T21, } \\
\text { T24, T25, T26, } \\
\text { T27, T28, T29, } \\
\text { T30, T31, T32, } \\
\text { T33, T35, T36 } \\
\text { T38, T39, T40 }\end{array}$ \\
\hline $\begin{array}{l}\text { Öğretim programlarının } \\
\text { farklı öğrenme alanlarındaki } \\
\text { bilimsel süreç becerilerinin } \\
\text { karşılaştırılması }\end{array}$ & $\begin{array}{l}2005 \text { yılı öğretim programı BSB açısından daha } \\
\text { zengin içeriğe sahiptir. }\end{array}$ & T10 \\
\hline
\end{tabular}




\begin{tabular}{|c|c|c|}
\hline $\begin{array}{l}\text { Bilimsel süreç becerileri ile } \\
\text { ilgili kazanımlar açısından } \\
\text { geliştirilmiş etkinliklerin } \\
\text { öğrenci başarısına etkisinin } \\
\text { araştırılması }\end{array}$ & $\begin{array}{l}\text { Bilimsel süreç becerileri ile ilgili kazanımlar } \\
\text { açısından geliştirilmiş etkinlikler başarıyı } \\
\text { artırmada etkilidir. }\end{array}$ & $\mathrm{T} 12, \mathrm{~T} 23$ \\
\hline $\begin{array}{l}\text { 1926, 1936, } 1948 \text { ve } 1968 \text { yılı } \\
\text { İlkokul müfredatlarına göre } \\
\text { hazırlanan Fen } \\
\text { programlarının Bilimsel } \\
\text { Süreç Becerileri yönünden } \\
\text { analiz edilerek } 2013 \text { Fen } \\
\text { Bilimleri ders programıyla } \\
\text { karşılaştırmalı olarak } \\
\text { incelenmesi }\end{array}$ & $\begin{array}{l}\text { 2004-2013 programında yeni bir kavram olan } \\
\text { bilimsel süreç becerileri kazanımlarından } \\
\text { bazıları 1926, 1936, 1948, } 1968 \text { ilkokul } \\
\text { programlarının içeriğinde yer almakta ve } 2018 \\
\text { programında yer alan kazanımlarla benzer } \\
\text { özellikler göstermektedir. }\end{array}$ & T16 \\
\hline $\begin{array}{l}2013 \text { yılı ile } 2018 \text { yılı 5. Sınıf } \\
\text { Fen Bilimleri ders } \\
\text { kitaplarında yer alan } \\
\text { “Canlılar ve Hayat/Yaşam” } \\
\text { konu alanındaki ünitelerde } \\
\text { bulunan etkinlikleri bilimsel } \\
\text { süreç becerileri açısından } \\
\text { karşılaştırarak incelemek }\end{array}$ & $\begin{array}{l}2013 \text { yılı 5. sinıf Fen Bilimleri ders kitabında yer } \\
\text { alan "Canlılar ve Yaşam" konu alanın } \\
\text { kapsayan ünitelerde daha fazla kazanım ve } \\
\text { etkinlik yer alırken söz konusu ünitelerin } \\
\text { bilimsel süreç becerileri açısından da daha } \\
\text { zengin olduğu görülmüştür. } 2018 \text { yılında ise } \\
\text { kazanımların sadeleştirildiği, etkinlik sayısının } \\
\text { azaltıldığı ve bilimsel süreç becerilerine daha az } \\
\text { yer verildiği tespit edilmiştir. }\end{array}$ & T18 \\
\hline $\begin{array}{l}\text { Devlet ve özel okullardaki } 6 . \\
\text { sınıf bilimsel süreç } \\
\text { becerilerinin karşılaştırılması }\end{array}$ & $\begin{array}{l}\text { Bilimsel süreç becerileri açısından özel okullar } \\
\text { lehine anlamlı bir farkın olduğu sonucuna } \\
\text { ulaşılmıştır. }\end{array}$ & T20 \\
\hline $\begin{array}{l}\text { OKS, SBS ve TEOG içerisinde } \\
\text { bulunan Fen Bilimleri testi } \\
\text { sorularının bilimsel süreç } \\
\text { becerilerine göre incelenmesi }\end{array}$ & $\begin{array}{l}\text { Bilimsel süreç becerilerinden 'gözlem' } \\
\text { basamağını desteklemeye yönelik soruların } \\
\text { diğerlerine göre daha fazla olduğu, sonrasında } \\
\text { ise 'çıarım yapma' becerisi geldiği, en az yer } \\
\text { verilen basamağın üst düzey düşünme } \\
\text { becerilerinden 'hipotez kurma' basamağ1 } \\
\text { olduğu görülmüştür }\end{array}$ & T22 \\
\hline $\begin{array}{l}\text { İlköğretim } 6,7 \text { ve } 8 \text {. sinıf fen } \\
\text { bilimleri dersi öğretim } \\
\text { programlarının öğrencilerin } \\
\text { bilimsel süreç becerilerine } \\
\text { etkisini incelemek }\end{array}$ & $\begin{array}{l}\text { Öğrencilerin bilimsel süreç beceri düzeylerinin } \\
\text { orta düzeyde olduğu tespit edilmiştir. }\end{array}$ & T34 \\
\hline
\end{tabular}

Tablo 1 incelendiğinde, lisansüstü tezlerde kullanılan yöntem/tekniğin BSB'ne etkisini araştıran tezlerin çoğunlukta olduğu ve tezlerde kullanılan yöntem ve tekniklerin bilimsel süreç becerilerini olumlu yönde arttırdığına yönelik sonuçlara

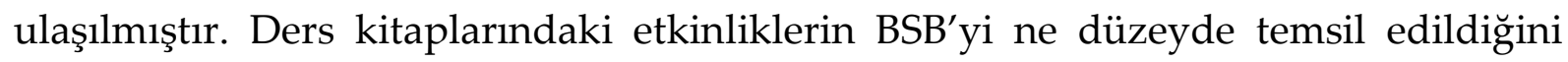
belirleyen çalışmalarda gözlem yapma, karşılaştırma, iletişim kurma, verileri toplama ve kaydetme, tahmin etme, verileri yorumlama becerilerine daha fazla yer verildiğ $i$ görülmüştür. BSB ile ilgili kazanımlar açısından geliştirilmiş etkinliklerin öğrenci başarısına etkisinin araştıııldığı çalışmalarda, etkinliklerin başarıyı artırmada etkili 
olduğu ve öğrencilerin BSB'ni okul, öğretim programı, merkezi sınavlar yönünden karşılaştırmayı amaçlayan çalışmaların da olduğu görülmüştür.

\section{Sonuç, Tartışma ve Öneriler}

Türkiye'de BSB ile ilgili fen eğitimi alanında yapılmış olan tezlerin incelenmesinin amaçlandığı bu çalışmada, fen eğitimi alanında tamamlanmış 40 tezin; tez türüne, yıllara, araştırma konularına, araştırma yöntemlerine, araştırma desenlerine, örneklem gruplarına, örneklem büyüklüklerine, veri toplama araçlarına, veri analiz türlerine, amaç-sonuç ilişkisine göre dağılımı analiz edilerek incelenmiştir.

BSB ile ilgili 2015-2021 yılları arasında yapılan tezler türlerine ve yayınlandıkları yıllara göre incelendiğinde tezlerin büyük çoğunluğunun yüksek lisans tezinden oluştuğu, belirtilen yıllar arasında en fazla tezin 2019 yılında yayınlandığı, diğer yıllarda ise yaklaşık olarak aynı sayıda tezin yayınlandığı görülmüştür. Son yıllarda bilimsel süreç becerilerinin özellikle fen eğitim programında farklı alanlarda yer alması, bilimsel süreç becerilerini konu edinen tezlerin artışına yol açtı̆̆ değerlendirilmektedir. BSB'ye yönelik tezlerin en fazla 2019 yılında yayınlanmasının sebebinin ülkemizde yapılan 2018 fen öğretim programı değişikliğinde temel beceriler altında bilimsel süreç becerilerine yer verilmiş olması olduğu düşünülmektedir (MEB, 2018). Ancak 2020 yılında tamamlanan lisansüstü tezlerinin 2019 yılına kıyasla daha az sayıda olmasının sebebi olarak, 2020 yılında tüm dünyayı etkisi altına alan Covid 19 pandemisi sebebiyle yapılan uzaktan eğitim uygulamaları olduğu düşünülmektedir.

İncelenen tezler araştırma konularına göre ele alındığında probleme dayalı öğrenme, fen öğretim programı, STEM, argümantasyon, dijital öyküleme, proje tabanlı öğrenme, GEMS programı, robotik uygulamaları konuları öne çıkmaktadır. Kaptan ve Korkmaz (2001)'e göre probleme dayalı öğrenme öğrencilerin bilimsel süreç becerilerinin gelişmesinde etkili bir öğrenme yöntemidir. Celep ve Bacanak, (2013) çalışmalarında bu çalışmanın sonuçları ile benzer şekilde son yıllarda yapılan çalışmalarda probleme dayalı fen öğrenmenin ortak noktalarından biri olan bilimsel süreç becerilerinin kazandırılmasına ve geliştirilmesine önem verildiğini ve fen eğitimi alanında yapılan literatür incelendiğinde farklı öğrenme yöntemlerinin bilimsel süreç becerilerinin gelişimine etkisinin araştırıldı̆̆ını belirtmiştir. Fen öğretim programlarında son yıllarda yapılan değişikliklerde bilimsel süreç becerilerinin sıklıkla yer alması ise yapılan çalışmaları öğretim programlarını bu yönden incelemeye yönlendirmiştir. 2018 yılından yenilenen öğretim programlarında bilimsel süreç becerilerinin mühendislik ve tasarım becerileri ile birlikte ele alındığ 1 görülmektedir (MEB, 2018). Bu bağlamda 2015-2020 yılları arasındaki incelenen tezlerde 2018 yılından sonra konu alanı olarak STEM seçilmesinin sebebinin son öğretim programındaki bilimsel süreç becerilerinin mühendislik ve tasarım ile ilişkilendirilmesi olduğu düşünülmektedir. 
Türkiye'de BSB'ye yönelik fen alanında yapılan tezlerde araştırma yöntemi olarak çoğunlukla nicel yöntem tercih edilirken, karma yöntemin de oran olarak nicel yönteme yakın olduğu, nitel yöntemin ise oranının diğerlerine göre oldukça düşük olduğu görülmektedir. Yapılan bu çalışmanın sonuçları ile benzer şekilde Caymaz, (2020) fen eğitimine yönelik elektrik konusu alanında yapılan tezleri incelediği çalışmasında araştırma yöntemi olarak nicel yöntemin diğerlerine göre daha fazla kullanıldı̆̆ı; Gül ve Cebesoy, (2019) çalışmalarında fen öğretmenlerine yönelik yapılan tezleri inceleyerek nicel araştırma yönteminin çoğunlukta olduğunu belirtmişlerdir. Yapılan bu çalışmanın sonuçlarından farklı olarak ise, Hastürk ve Dönmez, (2020) çalışmalarında fen eğitimi alanında yapılan doktora tezlerini incelemiş ve karma yöntemin diğer yöntemlerden daha fazla kullanıldığını; Yağan ve Çubukçu (2021) inceledikleri doktora tezlerinde karma yöntemin diğer yöntemlere göre daha fazla tercih edildiğini belirtmişlerdir.

İncelenen tezler araştırma desenlerine göre incelendiğinde deneysel desenin ağırlıklı olarak kullanıldığı görülmektedir. Bir araştırmada araştırma yönteminin yeterliliği önemli bir faktördür ve araştırmanın türüne göre dikkatli bir şekilde belirlenmelidir (Campbell ve Stanley, 1966; Fraenkel ve Wallen, 2003; Gliner, Morgan ve Leech, 2011; Sönmez ve Alacapınar, 2016). Çünkü araştırma yöntemi ve deseni çalışmanın örneklem grubunu ve veri toplama aracı gibi kısımları doğrudan etkilemektedir (Zorlu ve Zorlu, 2018). Bu çalışmanın sonuçları ile benzer şekilde Bayraklı (2018) Türkiye' de yapılan 2008-2018 yılları arasındaki fen eğitimi alanındaki tezleri inceleyerek nicel araştırma yönteminin çoğunlukta olduğu tezlerde en çok deneysel yöntemin kullanıldı̆̆ını belirlemiştir. Yapılan nicel araştırmalarda çoğunlukla deneysel desenin tercih edilmesinin sebebi, bilimsel süreç becerilerinin etkisini gözlemek deneysel desenlerin daha uygun olduğu düşünülebilir.

Fen eğitimi alanında BSB ile ilgili yapılan tezler örneklem grubuna göre incelendiğinde yedinci sınıf ve altıncı sınıf öğrencilerinin ön plana çıtı̆̆ görülmektedir. BSB'ye yönelik çalışmalarda örneklem gruplarının belirlenmesinde sınıf düzeyini belirlerken araştırılan konunun önemli olduğu düşünülmektedir. Benzer şekilde Ayvacı ve Altınok (2018) çalışmalarında Türkiye'deki 2005 - 2018 yılları arasındaki 1şık kavramına yönelik tezleri inceleyerek örneklem grubunun çoğunlukla yedinci sınıflardan oluştuğunu tespit etmişler ve bunun sebebini de inceledikleri konunun kazanımlarının yedinci sınıf öğretim programında yoğun olması olarak açıklamışlardır. Bu doğrultuda yapılan çalışmanın sonuçlarına göre bilimsel süreç becerilerine yönelik kazanımların fen bilimleri dersi öğretim programında altıncı ve yedinci sınıflarda ağırlıklı olduğu söylenebilir. Araştırma kapsamında incelenen çalışmalar örneklem büyüklükleri bakımından ele alındığında tezlerde en fazla 41-60 aralığında katılımcının bulunduğu görülmektedir. Benzer şekilde Karakuş (2020) tarafından yürütülen çalışmada, Türkiye'de sosyal bilgiler eğitimi alanında yapılan lisansüstü tez çalışmalarının analizinde örneklem büyüklüğünün 0-50 katılımcı 
aralığında olduğu tespit edilmiş, bunun sebebi ise tezlerin deney ve kontrol gruplu nicel çalışmalar olması ile açıklanmıştır.

BSB ile ilgili 2015-2021 yılları arasında yapılan tezler veri toplama araçlarına göre incelendiğinde tezlerde veri toplama aracı olarak en fazla bilimsel süreç becerileri testinin, devamında ise başarı testinin kullanıldığı görülmüştür. İncelenen tezlerin BSB'ye yönelik olmasından dolayı veri toplama aracı olarak BSBT'nin kullanılması çalışmanın doğal sonucu olarak görülmektedir. Özkan ve Kılıcıoğlu (2020)'ye göre bir bireyin sahip olduğu bilimsel süreç becerilerinin ortaya çıkarılması öğretime yönelik başarısının seyrinde izlenen en önemli adımlardan bir tanesidir. İncelen çalışmaların veri analiz türlerine bakıldığında tezlerde kullanılan araştırma yöntemi ve veri toplama araçlarına paralel olarak $\mathrm{t}$ testinin çoğunlukta olduğu, nitel ve karma yöntemin kullanıldığı tezlerde içerik analizinin yoğunlukta olduğu görülmektedir. Yapılan bu çalışmada $t$ testinin çoğunlukta olması deney ve kontrol gruplu iki grubun araştırmaya dahil olmasının sonucu olarak düşünülmektedir. Yapılan çalışmanın sonuçları ile benzer şekilde İlhan (2011) çalışmasında 2005-2009 yılları arasındaki incelediği lisansüstü tezlerde veri analiz yöntemi olarak en fazla t-testi kullanıldığını ve özellikle deneysel yöntemin kullanıldığı araştırmalarda sıklıkla kullanılan t-testinin iki grubun karşılaştırılmasına yönelik araştırmaların çoğunlukta olduğu sonucunu ortaya koyduğunu belirtmiştir.

İncelenen tezler amaç-sonuç ilişkisi bakımından incelendiğinde, çalışmalarda kullanılan öğretim yöntem ve tekniğinin BSB'ye olan etkisini araştırmaların diğerlerine göre çoğunlukta olduğu ve öğretim yöntem ve tekniklerin BSB'ye etkisinin olumlu yönde olduğu tespit belirlenmiştir. Bu doğrultuda incelenen tezlerde kullanılan örnek olay, proje tabanlı öğrenme, dijital öyküleme, kuantum öğrenme modeli, robotik kodlama, araştırma sorgulama, tasarım temelli öğrenme, GEMS, FeTeMM, probleme dayalı öğrenme, argümantasyon, STEM, TGA, okul dışı öğrenme, çoklu modsal betimleme ve modellemeye dayalı öğrenme yöntemlerinin bilimsel süreç becerilerini geliştirmede etkili olduğu sonucuna varılabilir. Ayrıca yapılan çalışmalarda ders kitapları ve öğretim programları da BSB'yi temsil etme bakımından incelenerek ders kitaplarında gözlem yapma, karşılaştırma, iletişim kurma, verileri toplama ve kaydetme, tahmin etme, verileri yorumlama becerilerine daha fazla yer verildiği saptanmıştır. Arslan ve Tertemiz (2004)'e göre eğitimde edinilmesi istenen bazı bilgi ve becerilere yönelik kazanımlar öğrencilere öğretmenler, ders kitapları ve öğretim programları ile sağlanmaktadır.

Sonuç olarak fen eğitimi alanında BSB ile ilgili Türkiye'de son yıllarda yapılan lisansüstü tezlerinin incelendiği bu çalışmada BSB'nin öğretim programlarında yer almaya başladığı yıl, ders kitaplarında değinilen kazanımlar gibi değişkenlerin yapılan çalışmalardaki öğretim yöntem ve tekniğinin, araştırma yönteminin, araştırma deseninin, örneklem grubu ve büyüklügünün, veri toplama araçlarının ve analiz türünün bütüncül bir bakış açısıyla bağlantılı olduğu görülmüştür. 
Yapılan bu meta-sentez çalışmasının sonuçları doğrultusunda ileride BSB'ye yönelik yapılacak olan araştırmalara ışık tutması açısından sunulan öneriler aşağıda verilmiştir.

- Bu araştırma yalnızca Türkiye'deki BSB ile ilgili yapılan tezlerin incelenmesine yönelik olduğundan uluslararası düzeyde benzeri çalışmalar yapılabilir.

- İncelenen tezler araştırma kapsamında ortaokul fen bilimleri alanına yönelik olup, BSB ile ilgili ortaöğretim ve yükseköğretim düzeylerine yönelik tezler incelenebilir.

- İncelenen tezlerde araştırma yöntemi olarak nitel yöntemin diğer yöntemlere göre daha az kullanılmasının sebepleri derinlemesine araştırılabilir.

- BSB'ye yönelik etkinlik planlayan öğretmenler ders anlatımında bu çalışmanın sonuçlarının kullanılan öğretim yöntem ve teknikler açısından inceleyebilir.

\section{Etik Beyan}

“Fen Eğitimi Alanında Yapılan Bilimsel Süreç Becerilerini İçeren Tezlerin İncelenmesi: Meta-Sentez Çalışması" başlıklı çalışmanın yazım sürecinde bilimsel etik ve alıntı kurallarına uyulmuş; toplanan veriler üzerinde herhangi bir tahrifat yapılmamış ve bu çalışma herhangi başka bir akademik yayın ortamına değerlendirme için gönderilmemiştir.

\section{Kaynaklar}

Aktamış H. \& Şahin-Pekmez, E. (2011). Fen ve teknoloji dersine yönelik bilimsel süreç becerileri ölçeği geliştirme çalışması, Buca Eğitim Fakültesi Dergisi, 30, 192-205.

Alisinanoğlu, F., Bay, D.N. \& Şimşek, Ö. (2014). Okul öncesi eğitimde okul aile iş birliği ölçeğinin geçerlik ve güvenirlik çalışması, Ahi Evran Üniversitesi Kırşehir Ĕ̆gitim Fakültesi Dergisi, 15(1), 1-13.

Anagün, Ş.S. \& Yaşar, Ş. (2009). İlköğretim beşinci sınıf fen ve teknoloji dersinde bilimsel süreç becerilerinin geliştirilmesi, İlköğretim Online, 8(3), 843-865.

Arslan, A.G. \& Tertemiz, N. (2004). İlköğretimde bilimsel süreç becerilerinin geliştirilmesi. Türk Ĕgitim Bilimleri Dergisi, 4(2), 479-492.

Aydoğdu, B., Tatar, N., Yıldız, E. \& Buldur, S. (2012). İlköğretim öğrencilerine yönelik bilimsel süreç becerileri ölçeğinin geliştirilmesi. Kuramsal Eğitim Bilim Dergisi, 5(3). 292-311.

Aydınlı, E. (2007). İlköğretim 6, 7 ve 8. sını öğrencilerinin bilimsel süreç becerilerine ilişkin performanslarının değerlendirilmesi. Yayınlanmamış Yüksek Lisans Tezi. Gazi Üniversitesi Eğitim Bilimleri Enstitüsü: Ankara.

Ayvacı, H.Ş., \& Altınok, O. (2019). Türkiye'de yürütülen tezlerin tematik incelenmesi: Işık kavramı Örneği. Trakya Ĕ̆itim Dergisi, 9(3), 549-563.

Bahar, M (Ed.). (2006). Fen ve Teknoloji Öğretimi. Ankara: Pegema Yayıncılık.

Başdă̆, G. (2006). 2000 yılı fen bilgisi dersi ve 2004 yılı fen ve teknoloji dersi öğretim programlarının bilimsel süreç becerileri yönünden karşılaştırılması, Yayımlanmamış Yüksek Lisans Tezi, Gazi Üniversitesi Eğitim Bilimleri Enstitüsü, Ankara. 
Batı, K. \& Kaptan, F. (2013). Bilimsel süreç becerilerine dayalı ilköğretim fen eğitiminin bilimsel problem çözme becerilerine etkisi, İlköğretim Online, 12(2), 512-527.

Batı, K., Ertürk, G. \& Kaptan, F. (2010). The awareness levels of pre-school education teachers regarding science process skills. World Conference On Educational Sciences, 2, 1993-1999.

Bowen, G.M.\& Roth, W.-M. (2005). Data and graph interpretation practices among preservice science teachers. Journal of Research in Science Teaching, 42(10), 1063-1088. https://doi.org/10.1002/tea.20086

Campbell, D.T. \& Stanley, J.C. (1966). Experimental and quasi-experimental designs for research. chicago: Rand McNally \& Company.

Carin, A.A. \& Bass, J.E., (2001). Teaching science as inquiry. Merrill Prentice Hall.

Caymaz, B. (2020). Türkiye'de elektrik konusuyla ilgili fen eğitimi alanında yapılan tez çalışmalarının içerik analizi. İnönü Üniversitesi Eğitim Fakültesi Dergisi,21(2), 701718. https://doi.org/10.17679/inuefd.642759

Celep, A. \& Bacanak, A. (2013). Yüksek lisans yapan öğretmenlerin bilimsel süreç becerileri ve kazandırılması hakkındaki görüşleri. Türk Fen Eğitimi Dergisi, 10(1), (56-78).

Çakar, E. (2008). 5. sımı fen ve teknoloji programının bilimsel süreç beceriler kazanımlarının gerçekleşme düzeylerinin belirlenmesi. Yayınlanmamış Yüksek Lisans Tezi. Süleyman Demirel Üniversitesi, Isparta.

Çalık, M. \& Sözbilir, M. (2014). İçerik analizinin parametreleri, Eğitim ve Bilim, 39(174), 33-38. http://dx.doi.org/10.15390/EB.2014.3412

Dökme İ., (2005). Milli eğitim bakanlığı (MEB) ilköğretim 6. sınıf fen bilgisi ders kitabının bilimsel süreç becerileri yönünden değerlendirilmesi, İlköğretim Online, 4(1), 7-17.

Farsakoğlu, Ö.F., Şahin, Ç., Karslı, F., Akpınar, M., \& Ültay, N. (2008). A study on awareness levels on prospective science teachers on science process skills in science education. World Applied Science Journal, 4(2) 174-182.

Finfgeld, D.L. (2003). Metasyntesis: the state of the art-so far. qualitative health research, 13, 893-904. https://doi.org/10.1177/1049732303253462

Fraenkel, J.R. \& Wallen, N.E. (2003). How to design and evaluate research in education. Mcgraw-Hill.

Gliner, J.A., Morgan, G.A., \& Leech, N.L. (2011). Research methods in applied settings: an integrated approach to design and analysis, (2nd Edition). Routledge. https://doi.org/10.4324/9780203843109

Hazır, A. Türkmen, L. (2008). İlköğretim 5. Sınıf öğrencilerinin bilimsel süreç beceri düzeyleri. Selçuk Üniversitesi Ahmet Keleşoğlu Eğitim Fakültesi Dergisi, 26, 81-96.

İlhan, A. (2011). Matematik eğitimi araştırmalarında tematik ve metodolojik eğilimler: uluslararası bir çözümleme. Yayımlanmamış Yüksek Lisans Tezi. Eskişehir Osmangazi Üniversitesi Eğitim Bilimleri Enstitüsü. Eskişehir.

Kaptan, F. (1999). Fen bilgisi öğretimi. Öğretmen Kitapları Dizisi. Milli Eğitim Basımevi.

Kaptan, F. \& Korkmaz, H. (2002). PDÖ yaklaşımının hizmet öncesi fen öğretmenlerinin problem çözme becerileri ve öz yeterlik, inanç düzeylerine etkisi. $V$. Ulusal fen bilimleri ve matematik eğitimi kongresi bildiri kitabı, Cilt 2, Ankara. 
Karakuş, S. (2020). Türkiye' de sosyal bilgiler eğitiminde kavramlar konusunda yapılan yüksek lisans ve doktora tezlerinin incelenmesi. Academia Eğitim Araştırmaları Dergisi, 5(1), 6176.

Karar, E.E. (2011). Illköğretim 8. sınıf öğrencilerinin bilimsel süreç becerilerinin bazı değişkenler açısından incelenmesi. Yayınlanmamış Yüksek Lisans Tezi. Adnan Menderes Üniversitesi, Aydın

Karslı, F., Şahin, Ç., \& Ayas, A.P. (2009). Determining science teachers' ideas about the science process skills: a case study. Procedia Social and Behavioral Sciences, 1, 890-895.

https://doi.org/10.1016/j.sbspro.2009.01.158

Karslı F., \& Ayas A. P, (2013). Fen ve teknoloji dersi öğretmen adaylarının bilimsel süreç becerilerinin ölçülmesine ilişkin bir test geliştirme çalışması, Türk Fen Eğitimi Dergisi, $10(2), 66-84$.

Kozcu Çakır N., \& Sarıkaya M. (2018). Fen bilgisi öğretmen adaylarının bilimsel süreç becerilerinin değerlendirilmesi, Türkish Studies, 13(4), 859-884.

http://dx.doi.org/10.7827/TurkishStudies.12823

Kaymakcı, G. (2014). Ortaokul öğrencilerinin problem çözme, bilimsel süreç becerilerinin ve öğrenme stillerinin bazı değişkenlere göre araştırılması. Yayınlanmamış Yüksek Lisans Tezi. Muğla Sitkı Kocaman Üniversitesi, Muğla

Kefi, S. (2018) Temel bilimsel süreç becerileri kullanma düzeyi ölçeği: ebeveyn formunun geçerlilik ve güvenilirlik çalışması, Kastamonu Education Journal, 26 (3), 613-628. https://doi.org/10.24106/kefdergi.379210

MEB (2005). İlköğretim fen ve teknoloji dersi öğretim programı. Ankara.

MEB (2013). İlköğretim kurumları (ilkokullar ve ortaokullar) fen bilimleri dersi (3,4,5,6,7 ve 8. sinfflar) öğretim programı. Ankara.

MEB (2013). Okul öncesi eğitim programı. Ankara.

MEB (2018). Fen bilimleri dersi öğretim programı (ilkokul ve ortaokul 3, 4, 5, 6, 7 ve 8. sinıflar). Ankara.

Myers, B.E., Washburn, S.G. \& Dyer, J.E. (2004). Assessing agriculture teachers' capacity for teaching science integrated process skills, Journal of Southern Agricultural Education Research, 54(1), 74-85.

Özdemir, M., Özdemir, O., \& Parmaksız, R.Ş. (2016). İlkokul öğrencilerinin bilimsel süreç becerilerinin ve okuduğunu anlama düzeylerinin incelenmesi. Turkish Studies, 11(3),1829-1848.

Özdemir Tümer, H. (2009). İlköğretim 5. sınf öğrencilerinin bilimsel süreç becerilerine sahip olma düzeyleri (Afyonkarahisar İli Örneği). Yayınlanmamış Yüksek Lisans Tezi. Afyon Kocatepe Üniversitesi, Afyonkarahisar

Özkan, T., \& Elif, A.Ç. I. L. (2020). Matematikte bilimsel süreç becerileri: test geliştirme çalışması. Necatibey Eğitim Fakültesi Elektronik Fen ve Matematik Eğitimi Dergisi, 14(1), 415-449. https://doi.org/10.17522/balikesirnef.660393

Öztürk, N. (2008). İlköğretim 7.sınfföğrencilerinin fen ve teknoloji dersinde bilimsel süreç becerilerini kazanma düzeyleri. Yayınlanmamış Yüksek Lisans Tezi. Eskişehir Osman Gazi Üniversitesi, Eskişehir. 
Padilla, M.J., Okey, J.R \& Dillashaw, F.G. (1983). The relationship between science process skills and formal thinking abilities. Journal of Research in Science Teaching, 20(3), 239-246. https://doi.org/10.1002/tea.3660200308

Rehorek, J., S. (2004). Inquiry-based teaching: An example of descriptive science in action, american biology teacher, 66(7), 493-500. https://doi.org/10.2307/4451726

Rezba, R. J., Sprague, C., Fiel, R. L., \& Funk, H. J. (1995). Learning and assesing science process skills. Kendall/Hunt Publishing Company.

Sönmez, D. \& Hastürk, G., (2020). Türkiye' de fen eğitimi alanında doktora düzeyinde yapılan tez çalışmalarının bibliyografik analizi. İnsan ve Toplum Bilimleri Araştırmaları Dergisi, 9(5), 3174-3194. https://doi.org/10.15869/itobiad.736128

Sönmez, V. \& Alacapınar, F. G. (2016). Örneklendirilmiş bilimsel araştırma yöntemleri. Ankara: Anı Yayınevi.

Şimşek-Çetin Ö., Bay N. D., \& Alisinanoğlu F., (2014). Ebeveyn okuma inanç ölçeği'nin Türkçeye uyarlama çalışması. Turkish Studies, 9(2), 1441-1458.

Şahin-Pekmez, E., Aktamış, H., \& Can, B. (2010). Fen laboratuvarı dersinin öğretmen adaylarının bilimsel süreç becerileri ve bilimsel yaratıcılıklarına etkisi. İnönü Üniversitesi Ĕ̆itim Fakültesi Dergisi, 11(1), 93-112.

Tan, M., \& Temiz, B. K. (2003). Fen öğretiminde bilimsel süreç becerilerinin yeri önemi. Pamukkale Üniversitesi Eğitim Fakültesi Dergisi, 1(13):89-101.

Tobin, K. G. \& Capie, W. (1982). Relationships between formall reasoning ability, locus of control, academic engagement and integrated process skill achievement. Journal of Research In Science Teaching, 19(2), 113-121. https://doi.org/10.1002/tea.3660190203

Türkmen, H. \& Kandemir, M. (2011). Öğretmenlerin bilimsel süreç becerileri öğrenme algıları üzerine bir durum çalışması. Journal of European Education, 1(1), 15-24.

Vitti, D. \& Torres, A., (2006). Practicing science process skills at home a handbook for parents, May 2006.

Yıldırım M., Çalık M., \& Özmen H., (2016). A Meta-synthesis of turkish studies in science process skills, International Journal of Environmental \& Sctence Education, 11(14), 65186539.

Zorlu F., Zorlu Y., Sezek F., \&Akkuş H. (2014). Ortaokul sekizinci sınıf öğrencilerinin bilimsel süreç becerileri ile seviye belirleme sınavı sonuçlarının karşılaştırılması, EKEV Akademi Dergisi, 59, 519-532.

Zorlu, F., \& Zorlu, Y. (2019). Eğitim alanında Solomon deneysel deseni ile gerçekleştirilen çalışmaların incelenmesi: bir tematik analiz çalışması. Kastamonu Ĕ̆itim Dergisi, 27(4), 1623-1636. https://doi.org/10.24106/kefdergi.3188

Ek 1: Meta-sentez araştırması kapsamında incelenen lisansüstü tezler:

T1. Sibel Kahveci, (2020). Fen Bilimleri Ders Kitaplarının Bilimsel Süreç Becerileri, Sorgulayıc1Araştırmaya Dayalı Öğretim Yönteminin Düzeyleri, Fetemm (Stem) Yaklaşımı ve Okunabilirlik Yönlerinden Analizi, Yüksek Lisans Tezi, Trakya Üniversitesi Fen Bilimleri Enstitüsü, Edirne. 
T2. Sevgi İzgi, (2020). Fen bilimleri dersi elektrik enerjisinin dönüşümü konusuna 5E modeli ile temellendirilmiş bilim, teknoloji, mühendislik ve matematik (STEM) yaklaşımının 7 . sınıf öğrencilerinin akademik başarı ve bilimsel süreç becerilerine etkisi, (Yayınlanmamış Yüksek Lisans Tezi), Mustafa Kemal Üniversitesi, Fen Bilimleri Enstitüsü, Hatay.

T3. Sultan Tatlısu, (2020). Fen Bilimleri Dersinde Argümantasyon Yönteminin Kullanılmasının 7.Sınıf Öğrencilerinin Fen Öğrenme Becerisi ve Bilimsel Süreç Becerileri Üzerine Etkisinin İncelenmesi Yüksek Lisans Tezi, Akdeniz Üniversitesi Eğitim Bilimleri Enstitüsü, Antalya.

T4. Zeynep İlben Turan, (2020). 6, 7 ve 8. Sınıf Fen Bilimleri Ders Kitaplarında Yer Alan "Madde ve Doğası" Konu Alanındaki Etkinliklerin Bilimsel Süreç Becerileri Açısından İncelenmesi, Recep Tayyip Erdoğan Üniversitesi Fen Bilimleri Enstitüsü, Rize.

T5. Gülgün Bakırlı, (2020). Probleme Dayalı Fen Öğrenme: Hipotez Test Etme Deneylerinin Akademik Başarıya ve Bilimsel Süreç Becerilerine Etkisi, Muğla Sıtkı Koçman Üniversitesi, Eğitim Bilimleri Enstitüsü, Muğla.

T6. Hülya Cömert, (2019). Argümantasyona Dayalı Öğretimin 8. Sınıf Öğrencilerinin Akademik Başarı, Kavramsal Anlama ve Bilimsel Süreç Becerilerine Etkisinin Öğrenme Stilleri Açısından İncelenmesi: Asitler ve Bazlar Konusu (Doktora Tezi), Marmara Üniversitesi, Türkiye.

T7. İdris Doğan, (2019). STEM Etkinliklerinin 7. Sınıf Öğrencilerinin Bilimsel Süreç Becerilerine, Fen ve STEM Tutumlarına ve Elektrik Enerjisi Ünitesindeki Başarılarına Etkisi. (Doktora Tezi), Balıkesir Üniversitesi, Balıkesir.

T8. Z. Dilek Öztürk, (2019). Fen Bilimleri Dersinde Probleme Dayalı Öğrenme Yönteminin Öğrencilerin Akademik Başarılarına ve Bilimsel Süreç Becerilerine Etkisi (Yüksek Lisans Tezi), Pamukkale Üniversitesi Eğitim Bilimleri Enstitüsü. Denizli.

T9. A. Emre Yılmaz, (2019). Fetemm Uygulamalarının Ortaokul 7.Sınıf Öğrencilerinin Fen Bilimleri Dersi Tutumlarına ve Bilimsel Süreç Becerilerine Etkisinin İncelenmesi, Abant İzzet Baysal Üniversitesi, Eğitim Bilimleri Enstitüsü, Bolu.

T10. Büşra A. Türk, (2019). 2005-2013 ve 2018 Yilları Fen Dersi Öğretim Programlarına Dayalı Ders Kitaplarının "Canlılar ve Hayat" Öğrenme Alanındaki Bilimsel Süreç Becerileri Açısından Karşılaştırılması Gazi Üniversitesi Eğitim Bilimleri Enstitüsü, Ankara.

T11. Çağla Aktürk, (2019). Gems Programının Kuvvet ve Hareket Ünitesinde 6.Sınıf Öğrencilerinin Temel Bilimsel Süreç Becerilerine ve Tutumlarına Etkisi, Yüksek Lisans Tezi, Ordu Üniversitesi, Ordu.

T12. Derya Yıldırım, (2019). Fen Bilimleri Eğitiminde Farklı Öğrenme Ortamları İçin Bilimsel Süreç Becerilerine Dayalı Etkinliklerin Tasarlanması ve Uygulanması, (Yüksek Lisans Tezi), Kastomonu Üniversitesi, Fen Bilimleri Enstitüsü, Kastomonu.

T13. Nesrin Koç, (2019). Tasarım Temellg Fen Eğitiminde Biltemm Uygulamalarının Bilimsel Süreç Becerilerine, Fetemm Meslek İlgilerine ve Stem Tutumlarına Etkisi, Yüksek Lisans Tezi). Frrat Üniversitesi, Eğitim Bilimleri Enstitüsü, Elazı̆̆. 
T14. Azat Kırtay, (2019). Fen Eğitiminde Robotik Uygulamaların Öğrencilerinbilimsel Süreç Becerileri ve Fen Eğitimine Yönelik Motivasyonlarına Etkisi (Yüksek Lisans Tezi) Mersin Üniversitesi, Eğitim Bilimleri Enstitüsü, Mersin.

T15, Gönül Tekiz, (2019). 7. Sınıf Fen Bilimleri Dersinde Araştırma Sorgulama Temelli Etkinliklerin Öğrencilerin Akademik Başarılarına, Tutumlarına ve Bilimsel Süreç Becerilerine Etkisi, (Yüksek Lisans Tezi), Aksaray Üniversitesi Fen Bilimleri Enstitüsü, Aksaray.

T16. M. Ali, Altınok, (2019). Cumhuriyetten Günümüze Fen Programlarında Bilimsel Süreç Becerileri ile Fen - Teknoloji - Toplum - Çevre Kazanımlarının Karşılaştırılmalı İncelenmesi, (Yüksek Lisans Tezi), Aksaray Üniversitesi, Fen Bilimler Enstitüsü, Aksaray.

T17, Gülsüm Kapan, (2019). 7. Sınıf Fen Bilimleri Dersi Elektrik Devreleri Ünitesinde Stem Uygulamalarının Akademik Başarı, Motivasyon ve Bilimsel Süreç Becerilerine Etkisinin İncelenmesi, (Yüksek Lisans Tezi), Zonguldak Bülent Ecevit Üniversitesi, Fen Bilimleri Enstitüsü, Zonguldak.

T18. Kezban Dişli Demiray, (2019). 2013 Yılı ile 2018 Yılı 5. Sınıf Fen Bilimleri Dersi Öğretim Programına Dayalı Ders Kitaplarında Yer Alan "Canlılar ve Yaşam” Konu Alanındaki Bilimsel Süreç Becerilerinin Karşılaştırılması, (Yüksek Lisans Tezi), Gazi Üniversitesi Eğitim Bilimleri Enstitüsü, Ankara.

T19. Kürşat Şimşek, (2019). Fen Bilimleri Dersi Madde ve Isı Ünitesinde Robotik Kodlama Uygulamalarının 6. Sınıf Öğrencilerinin Akademik Başarı ve Bilimsel Süreç Becerileri Üzerine Etkisinin İncelenmesi, (Yüksek Lisans Tezi), Marmara Üniversitesi Eğitim Bilimleri Enstitüsü, İstanbul.

T20. Ahmet Salman, (2019). Devlet ve Özel Okullardaki 6. Sınıf Öğrencilerin Fen Bilimleri Dersine Yönelik Tutum, Motivasyon ve Bilimsel Süreç Becerilerinin Karşılaştırılması ve Öğretmenlerin Programa İlişkin Görüşleri 'Ağrı İli Örneği' (Yüksek Lisans Tezi), Ağrı İbrahim Çeçen Üniversitesi Fen Bilimleri Enstitüsü, A

T21. S. Seray Erkoç, (2019). Kuantum Öğrenme Modeline Dayalı Fen Eğitiminin Ortaokul 5. Sınıf Öğrencilerinin Akademik Başarı ve Bilimsel Süreç Becerilerine Etkisi, (Yüksek Lisans Tezi). Amasya Üniversitesi Fen Bilimleri Enstitüsü, Amasya.

T22. Oya Arıkan, (2018). OKS, SBS ve TEOG Fen Bilimleri Testi Sorularının Bilimsel Süreç Becerileri ve Eleştirel Düşünme Becerilerine Göre İncelenmesi, (Yüksek Lisans Tezi), Kırıkkale Üniversitesi Fen Bilimleri Enstitüsü, Kırıkkale.

T23. S. Bilgili Kaya, (2018). Fen Bilimleri Dersinde Çevre Konularının Öğretiminde Bilimsel Süreç Becerilerine Dayalı Etkinliklerin Öğrenme Ürünlerine Etkisi (Doktora Tezi), Gazi Üniversitesi Eğitim Bilimleri Enstitüsü, Ankara.

T24. Miray Nasırlı, (2018). Fen Bilimleri Enstitüsü İlköğretim Anabilim Dalı Yüksek Lisans Tezi Elektriğin İletimi Ünitesinde Basit Araç Gereçlerle Yapılan Etkinliklerin (Hands-On Scıence) Bilimsel Süreç Becerilerine ve Akademik Başarıya Etkisinin Araştırılması, Kocaeli Üniversitesi, Kocaeli.

T25, Veli Çümen, (2018). Gems Tabanlı Öğrenme Programının 6.Sınıf Öğrencilerinin Yoğunluk Kavramı ile İlgili Başarılarına, Kavramsal Değişimlerine Ve Bilimsel Süreç Becerilerine 
Etkisinin İncelenmesi (Yüksek Lisans Tezi), Uşak Üniversitesi Fen Bilimleri Enstitüsü, Uşak.

T26. Hülya Söyleyici, (2018). Probleme Dayalı Öğrenmenin Ortaokul Öğrencilerinin Bilimsel Süreç Becerilerine, Tutumlarına ve Başarılarına Etkisinin İncelenmesi: Işık Ünitesi Örneği, Trakya Üniversitesi Fen Bilimleri Enstitüsü, Mersin.

T27. Mustafa Büyükcengiz, (2017). Dijital Öyküleme Metodunun Ortaokul Öğrencilerinin Fen Bilimleri Dersi Akademik Başarı, Bilimsel Süreç Becerileri ve Derse Yönelik Tutumlarına Etkisi, (Yüksek Lisans Tezi), Akdeniz Üniversitesi Eğitim Bilimleri Enstitüsü, Antalya.

T28. E. Keskin Kargın, (2017). Problem Çözme Yönteminin Ortaokul Öğrencilerinin Fen Bilimlerine Yönelik Tutum, Bilimsel Süreç Becerileri ve Akademik Başarılarına Etkisi Doktora Tezi, Uludağ Üniversitesi Eğitim Bilimleri Enstitüsü, Bursa.

T29. Bengü Bozlar, (2017). Proje Tabanlı Öğrenmenin 5.Sınıf Fen Bilimleri Dersinde Öğrencilerin Akademik Başarı ve Bilimsel Süreç Becerilerine Etkisi, (Yüksek Lisans Tezi), Çukurova Üniversitesi Sosyal Bilimler Enstitüsü, Adana.

T30. D. Mehmet Gençoğlan, (2017). Otantik Örnek Olay Destekli Argümantasyon Tabanlı Bilim Öğrenme Yaklaşımının 8. Sınıf Öğrencilerinin "Asitler ve Bazlar" Konusundaki Başarılarına, Tutum ve Bilimsel Süreç Becerilerine Etkisi, (Yüksek Lisans Tezi), Fen Bilgisi Eğitimi Anabilim Dalı, Kahramanmaraş.

T31. Elif Kara, Tahmin Et- Gözle-Açıkla Stratejisine Dayalı Fen Öğretiminin Ortaokul 5. Sınıf Öğrencilerinin Bilimsel Süreç Becerilerine ve Başarısına Etkisinin Araştırılması, (Yüksek Lisans Tezi), Marmara Üniversitesi Eğitim Bilimleri Enstitüsü, İstanbul.

T32. Zehra Erten, (2016). Fen Bilgisi Dersine Yönelik Okul Dışı Öğrenme Ortamları Etkinliklerinin Geliştirilmesi ve Öğrencilerin Bilimsel Süreç Becerilerine Etkisinin Değerlendirilmesi, (Yüksek Lisans Tezi), Erzincan Üniversitesi Fen Bilimleri Enstitüsü, Erzincan.

T33. Burcu Torun, (2016). Ortaokul 6. Sınıf Hücre Konusunda Dijital Öykü Kullanımının Öğrenci Başarısı, Tutumu ve Bilimsel Süreç Becerileri Üzerine Etkisi, (Yüksek Lisans Tezi), Kastamonu Üniversitesi Fen Bilimleri Enstitüsü, Kastamonu.

T34. Sabiha Aktaş, (2016). Ortaokul 6, 7 ve 8. Sınıf Fen Bilimleri Dersi Öğretim Programlarının Öğrencilerin Bilimsel Süreç Becerileri, Duygusal Zekâları, Bilişsel Stilleri ve Akademik Başarılarına Etkisi, Mustafa Kemal Üniversitesi Fen Bilimleri Enstitüsü, Hatay.

T35. Semra Demirçalı, (2016). Modellemeye Dayalı Fen Öğretiminin Öğrencilerin Akademik Başarılarına, Bilimsel Süreç Becerilerine ve Zihinsel Model Gelişimlerine Etkisi: 7. Sınıf "Güneş Sistemi ve Ötesi- Uzay Bilmecesi” Ünitesi Örneği, (Doktora Tezi), Gazi Üniversitesi Eğitim Bilimleri Enstitüsü, Ankara.

T36. Bayram Çınar, (2016). Bilimsel Gelişimin Tarihsel Süreçlerini İçeren Öykülerle Fen Derslerinin Desteklenmesinin Fene Yönelik Tutuma, Bilim İnsanı İmajına, Bilimsel Süreç Becerilerine ve Akademik Başarıya Etkisi, (Yüksek Lisans Tezi), Sakarya Üniversitesi Eğitim Bilimleri Enstitüsü, Sakarya.

T37. Fatma Turan, (2015). Ahi Üniversitesi Fen Bilimleri Enstitüsü Ortaokul 8.Sınıf Fen ve Teknoloji Öğretim Programı Çerçevesinde Ders Kitabının Bilimsel Süreç Becerileri 
Açısından Karşılaştırılması ve Bilimsel Süreç Becerilerinin Uygulanabilirliğine Yönelik Öğretmen Görüşleri, (Yüksek Lisans Tezi), Ahi Üniversitesi Fen Bilimleri Enstitüsü, Kırşehir.

T38, Fatmanur Yılmaz, (2015). Fen Bilimleri Öğretiminde Proje Tabanlı Öğrenme Yaklaşımının 6. Sınıf Öğrenci Başarısı ve Bilimsel Süreç Becerilerine Etkisi, Pamukkale Üniversitesi Eğitim Bilimleri Enstitüsü, Denizli.

T39. Zeynep Bodur, (2015). Sınıf Dışı Etkinliklerin Güneş Sistemi ve Ötesi Ünitesinde Ortaokul Yedinci Sınıf Öğrencilerinin Akademik Başarıları, Bilimsel Süreç Becerileri ve Motivasyonları Üzerine Etkisi Yüksek Lisans Tezi, Marmara Üniversitesi Eğitim Bilimleri Enstitüsü, İstanbul.

T40. Muhittin Öz, (2015). Öğrenme Amaçlı Yazma Aktivitelerinde Çoklu Modsal Betimleme Kullanımının 5. Sınıf Öğrencilerinin Öğrenmelerine, Bilimsel Süreç Becerilerine, Eleştirel Düşünmelerine ve Fen Bilimlerine Yönelik Tutumlarına Etkisi, (Yüksek Lisans Tezi), Kastamonu Üniversitesi Fen Bilimleri Enstitüsü, Kastamonu. 